\title{
Drying response of lime-mortar joints in granite masonry after an intense rainfall and after repointing
}

\author{
Lucie Fusade ${ }^{1 *} \mathbb{D}$, Scott Allan Orr ${ }^{1}$, Chris Wood ${ }^{2}$, Meriel O'Dowd ${ }^{3}$ and Heather Viles ${ }^{1}$
}

\begin{abstract}
When rain impacts a building façade, it is essential that once it has entered, it leaves by evaporation to help the building dry out. Accumulation of moisture can lead to internal dampness, mould and decay of valuable masonry by salt weathering. In a solid masonry wall where the stone is of low permeability, such as granite which is found in many historic buildings, rain water mainly enters and leaves through mortar joints. If granite stone masonry needs repointing, the repair mortar must allow the overall masonry to dry out. This study evaluates the drying response of various lime-based repointing mortars mixes in small granite stone masonry constructions (test walls) subjected to a simulated intense short rain event and then left to dry. It determines the moisture movement through mortar joints, the influence of materials, joint types and workmanship, and whether repointing could mitigate moisture ingress and help masonry dry out. This study developed a novel experimental protocol which allowed comparison of the drying response of different mortar types in a low-porosity stone masonry system and the effect of repointing. Five test walls were built of Cornish granite with five different lime mortar mixes combining NHL 3.5 (St Astier) gauged with non-hydraulic quicklime (Shap), quartz and calcitic sand and biomass wood ash as additives. Simulated intense rain was sprayed on each wall over a $3.25 \mathrm{~h}$ spell. Drying was monitored over a week with a microwave moisture device (MOIST350B). Measurements were done at surface and depth on both mortar joints and granite units. Each wall was then repointed with the same mortar mix initially used when built and the same rain simulation was performed to evaluate differences repointing could make to the moisture dynamics. The importance of mortar in dealing with moisture movements in the test wall and absorbing moisture from the stones was demonstrated. Gauged binder and wood ash additives decreased the capillary absorption capacity of mortars while retaining a good drying rate. This study has also showed that after repointing water did not penetrate as deep under the same conditions. Therefore repointing reduces the threat of water ingress and shows that it could be a suitable conservation intervention to mitigate water ingress and accelerate drying.
\end{abstract}

Keywords: Non-destructive testing, Evaporation, Test walls, NHL, Hot lime, Built heritage

\section{Introduction}

Many historic and traditional solid masonry walls in England and other temperate maritime environments are exposed to high amounts of rainfall and wind-driven rain (driving rain) [1]. When driving rain hits a building façade, even when a masonry wall is of considerable

\footnotetext{
*Correspondence: lucie.fusade@ouce.ox.ac.uk

${ }^{1}$ School of Geography and the Environment, University of Oxford, Oxford OX1 3QY, UK

Full list of author information is available at the end of the article
}

thickness (as often found in historic church towers) [2], it will enter the wall through mortar joints, cracks, and at the interface between stone and mortar [3]. Driving rain can lead to moisture ingress through the masonry wall resulting in liquid water ingress and/or internal dampness [4]. In addition, a lot of water can enter a wall from defects on the roof, parapets, and other elements that manage rainwater in building. Water is one of the main agents in the deterioration of building materials leading to chemical and physical weathering and surface erosion on brick, mortar and stone [5], biological growth [6], 
frost damage and salt efflorescence [4, 7] and damp internal conditions $[4,8]$. An increasing frequency of rainfall has therefore been identified as one of the main threats of climate change to historic buildings [9].

It is therefore essential that once it has entered, moisture leaves masonry by evaporation to help it dry, if only partially $[10,11]$. Most of the moisture movement occurs through mortar joints in a solid ashlar masonry wall. This is especially true for stone units of low permeability and low-porosity, such as granite, where rain water mainly enters and leaves through mortar joints [12-14]. During drying and evaporation, liquid water travels to the surface of building materials and can carry soluble salts that are present $[10,15]$. Mortar in joints should absorb moisture from the surrounding masonry units, by having a stronger capillary force than the stones with coarser pores [16]. If most of the evaporation occurs at the surface of the joints, then so will any salt crystallisation and efflorescence. This will minimise damage to the individual stones, such as disintegration. Climate change is expected to cause more driving rain and therefore which will increase the threats to masonry structure, mainly due to salt crystallisation $[17,18]$. The role and performance of mortar in absorbing moisture is becoming even more important.

A significant number of historic buildings, especially churches, in southwest England are built with hard low permeable stones, such as granite [19]. Buildings of low porosity stones often suffer from water ingress and high interior dampness if the mortar is also a dense and lowpermeable material that does not encourage evaporation through external walls $[2,4,14]$. Weathered and aged pointing mortar or previous interventions that suffer from the use of inappropriate materials or bad workmanship during repair can also prevent moisture from leaving the building [12]. The performance of the pointing mortar, and especially of repointing in the case of repair, is therefore critically important in reducing water penetration through the masonry and also to help it dry out $[20,21]$. Careful repointing is thus a preventive measure against the ingress of water and internal dampness $[4,14]$. It has also been shown that workmanship, which includes the comprehensive clearing of loose debris, careful compaction and filling [22], types of finishing [12] and protection of the new mortar, can significantly influence the water resistance of joints [23-25]. Rendering and grouting can be very effective at preventing moisture ingress and assisting drying, as the render would hold water before it enters into the masonry and grouting would fill in the voids that are pathways for liquid water [26]. However, in many cases for listed buildings repointing is often the only possibility because it is less visually intrusive, a minimal intervention and less costly. When deciding on a repair mortar for historic masonry it is essential to consider the material properties, the workmanship and the masonry type, in relation to the building's exposure and environmental conditions if it is to be effective [12, 27].

Research has been published on developing suitable mortars to use with granite. Mosquera et al. and O'Brien et al. argue that because the calcium in lime-based mortar reacts with sulphates from the environment and form salts that damage granite, cement with a high sand content should be used [28, 29]. However, as Hughes pointed out, the use of cement for historic buildings is usually inappropriate and not recommended; therefore appropriate lime mortars need to be developed [13]. In addition the amount of sulphate in the atmosphere has drastically reduced since the 1990s. Hughes et al. have tested several compositions of mortar for repointing granite, which included using quicklime [13]. Moreover, understanding the response of a masonry system to driving rain, comprising masonry units, mortar joints, but also a core filled with loose stones, rubble and mortar, is complex [30,31]. Therefore some studies have used test walls to understand the effect of water ingress and compare conservation treatments [3] and to evaluate the response of a specific material to driving rain, mainly focusing on brick walls [25, 32] and stone [33]. The bond of a range of pointing mortars with sandstone has also been evaluated with small masonry wall [34]. However, little investigation has been done which compares different mortars designed specifically for dense and exposed stone masonry and their drying performance using test walls.

Therefore, suitable lime mortars for pointing and repointing low porosity stone masonry walls needs to be designed and tested to establish how effective they are at helping the drying process. Testing needs to develop a tailored and comprehensive way of assessing and validating these mortars. This study specifically looks at how various lime-based repointing mortar mixes in a small and dense stone masonry system (granite test walls) respond to drying and evaporation after an intense short rain event. It aims to determine whether moisture movement happens through mortar joints, the influence of materials, joint types and workmanship, and whether repointing could mitigate moisture ingress and help masonry dry out.

\section{Materials and methods}

The experiment was designed to represent a low porosity masonry system, as often found in southwest England, exposed to high intensities of driving rain. For the purpose of enabling comparison between test walls and mortar joints the variables such as environmental variations, direct solar radiation and direct rainfall were minimised. 


\section{Granite}

In southwest England, Devon especially, a significant number of the historic buildings and churches with their tall towers are made of a grey granite, such as Dartmoor granite [19]. For this study, a light grey Cornish granite (Pipper and Sons) with an open porosity of $0.87 \pm 0.05 \%$ and a density of $2.89 \pm 0.05 \mathrm{~g} / \mathrm{cm}^{3}$ was selected.

\section{Lime mortar mixes and preparation}

The composition of the lime mortar mixes was decided based on results from previous research looking at mortar for highly exposed areas [35] and impermeable dense stone [13]. Natural hydraulic lime 3.5 (NHL) has been demonstrated to be suitable for conservation purposes [36-38], especially for exposed masonry as it has the ability to set in humid environmental conditions through hydration processes [39, 40]. Previous work [35] has shown the positive effects of using biomass wood ash in lime mortars for use in exposed buildings such as high open porosity and delayed capillarity saturation, which enables more water to be absorbed and a better ability to dry out. In recent years, experiments have been done to re-evaluate using quicklime, as it could be a more authentic method to make mortar and improve durability, adhesion and workability [41-43].

The binder:aggregate ratio by volume was $1: 3$, following repointing requirements $[36,44]$. To keep the same ratio by volume, the weight of the binder, sand and wood ash was adapted for each mortar mixes based on bulk densities. Table 1 summarises the composition of the mortars used in each wall. NHL (St Astier) gauged with nonhydraulic quicklime (Shap Lime $5 \mathrm{~mm}$ to dust) at 0.25 part of the binder ratio was used with quartz (Chardstock sand) and/or calcitic aggregates (Moreton Cullimore sand). Both sands showed a similar particle size distribution (from 0.76 to $4 \mathrm{~mm}$ ). Additives of biomass wood ash at $30 \%$ of the aggregates volume was also added in some mixes (Table 1). Wood ash was previously oven dried at $80{ }^{\circ} \mathrm{C}$ for $24 \mathrm{~h}$ and sieved to retain particles smaller than $2 \mathrm{~mm}$ (ranging from $0.4 \mu \mathrm{m}$ to $2 \mathrm{~mm}$ ). Finely granulated quicklime was added to the dried mixed NHL and aggregate, generating low heat in contact with moisture in the sand. Water was then added as necessary and quicklime was fully slaked when the mortar was used; avoiding visible lime inclusions at the surface of the joints.

As Table 1 shows, the composition of the mortar in each wall varies by one variable so that pairs of walls can be compared to each other to assess the effect of one specific material. For example, wall 1 and wall 2 are paired to compare the effect of using a binder gauged with quicklime (pair A), wall 2 and wall 5 are paired to identified the effect of wood ash (pair B) and wall 3 and wall 4 to compare the use of different aggregates (pair C).

During mixing, no specific water:binder ratio was specified but rather water was added as necessary to obtain similar consistency in all mixes ( $\pm 10 \mathrm{~mm}$ by flow), based on the experience of the mason. Flow tests were carried out on each mix with a flow table (Matest) following BS EN 1015 5-3:1999 [45], to ensure a similar consistency was obtained (110-125 mm for building the walls and $107-119 \mathrm{~mm}$ for repointing).

\section{Laboratory characterisation of mortar and granite samples} Five specimens of each mortar mix were made in the laboratory in prisms of $40 \mathrm{~mm} \times 40 \mathrm{~mm} \times 160 \mathrm{~mm}$ using polystyrene moulds. All specimens were demoulded after 5 days and kept for 90 days until testing in a ventilated environmental chamber (Sanyo-FE 300H/MP/R20) at

Table 1 Compositions of the mortar mixes in each wall and proportions of materials

\begin{tabular}{|c|c|c|c|c|c|c|c|c|}
\hline & & Binder & olume 1) & & Aggrega & (volume 3 ) & Paire & valls for \\
\hline & Mix \# & NHL 3.5 & $\begin{array}{l}\text { Gauged } \\
\text { with }\end{array}$ & $\begin{array}{l}\text { Quartz } \\
\text { sand }\end{array}$ & $\begin{array}{l}\text { Calcitic } \\
\text { sand }\end{array}$ & $\begin{array}{c}\text { Wood ash additives } \\
\text { (30\% of the aggregates) }\end{array}$ & con & rison \\
\hline $\begin{array}{l}\text { Wall } 1 \\
\text { (control }\end{array}$ & W1 & $100 \%$ & & $50 \%$ & $50 \%$ & & Pair & \\
\hline Wall 2 & W2 & $75 \%$ & $25 \%$ & $50 \%$ & $50 \%$ & & & Pair B \\
\hline Wall 3 & W3 & $75 \%$ & $25 \%$ & $70 \%$ & & $30 \%$ & & \\
\hline Wall 4 & W4 & $75 \%$ & $25 \%$ & & $70 \%$ & $30 \%$ & & \\
\hline Wall 5 & W5 & $75 \%$ & $25 \%$ & $35 \%$ & $35 \%$ & $30 \%$ & & Pair B \\
\hline
\end{tabular}

The grey box indicates that the material is present in the mix 
$20{ }^{\circ} \mathrm{C}\left( \pm 3{ }^{\circ} \mathrm{C}\right)$ and $65 \%( \pm 5 \%) \mathrm{RH}$. Curing samples in moulds may impact some properties, due to water extraction [46], but in this case (low permeability of stones) this impact might be negligible.

\section{Open porosity}

The open porosity (op) was evaluated following the gravimetric method adapted from the standard BS EN 1936:2006 [47]. Five half prisms of each mortar mix and three samples of granite of $50 \mathrm{~mm} \times 50 \mathrm{~mm}$ were placed in a desiccator under vacuum at low pressure (less than $15 \mathrm{mmHg}$ ) for $1 \mathrm{~h}$ and then allowed to soak in distilled water for $24 \mathrm{~h}$ at ambient temperature, enabling determination of the saturated mass ( $m s$ in $g$ ) and immersed mass ( $m h$ in $g$ ). The open porosity (\%) was calculated as the mean of the five replicates with formula (1):

$$
o p=\frac{m s-m d}{m s-m h} \times 100
$$

\section{Drying behaviour}

The drying rate was monitored for $100 \mathrm{~h}$ on laboratory samples left in the same sheltered area as the walls $\left.\left(16.7 \pm 1.5^{\circ} \mathrm{C}\right), 80.4 \pm 10 \%\right)$. Three replicates of each mortar mix in half prisms, having previously been fully saturated under vacuum to obtain a maximum water content, were used at 90 days. The change of mass $\left(m_{1}\right.$ in $\left.\mathrm{g}\right)$ was recorded every 8 to $12 \mathrm{~h}$ using a balance at $0.01 \mathrm{~g}$ precision (Sartorius). The water content $(W c)\left(\mathrm{g} / \mathrm{cm}^{3}\right)$ was calculated as a mean of the three replicates with the following formula (2):

$$
W c=\frac{(m 1-m d) \rho w}{V}
$$

where $m d(\mathrm{~g})$ is the oven dry mass of the replicates, $\rho w$ $\left(\mathrm{g} / \mathrm{cm}^{3}\right)$ the density of water at $20{ }^{\circ} \mathrm{C}$ degrees, and $V\left(\mathrm{~cm}^{3}\right)$ the volume of the sample [48].

\section{Capillary absorption}

The determination of the water absorption coefficient due to capillarity of hardened mortar followed both BS EN 1015-18:2002 [49] and EN 1925: 2000 [50] for highly absorbent stone. Samples were oven dried for $24 \mathrm{~h}$ at $70{ }^{\circ} \mathrm{C}\left( \pm 2{ }^{\circ} \mathrm{C}\right)$ to constant mass ( $m d$ in $\mathrm{g}$ ), cut in half, sealed using a moisture and vapour-proof sealant (Parafilm $\mathrm{M}$ ), and placed in $3 \mathrm{~mm}$ of distilled water. The mass of each of the six replicates at defined time was determined using a balance (Sartorius) at $0.01 \mathrm{~g}$ precision until full saturation of the samples. The increase in mass $\left(m_{1}\right.$ in g) by the surface immersed $(\mathrm{A})\left(\mathrm{g} / \mathrm{cm}^{2}\right)$ of each replicate was expressed as a function of the square root of time $\left(\sqrt{ } t_{1}\right)$ in minutes $\left(\mathrm{mn}^{0.5}\right)$. The water absorption coefficient by capillarity (WACC) $\left(\mathrm{g} / \mathrm{cm}^{2} \mathrm{~min}^{-0.5}\right)$ was determined by formula (3) given by the standard as a mean of the six replicates:

$$
W A C C=\frac{m 1-m d}{A \cdot \sqrt{ } t 1}
$$

\section{Water vapour permeability}

The water vapour permeability (Wvp) was determined following EN 1015-19:1999 [51] using the wet cup method. Disks of $12 \mathrm{~cm}$ diameter and $10 \mathrm{~cm}$ thickness were sealed on top of a cup containing a saturated solution of potassium nitrate $\left(\mathrm{KNO}_{3}\right)$ to provide a $\mathrm{RH}$ of 93.2\%, and kept in an environmental chamber (SanyoMLR-351) at $20{ }^{\circ} \mathrm{C}, 50 \% \mathrm{RH}$. The mass was recorded at intervals of $24 \mathrm{~h}$ for 7 days. The water vapour permeability $\left(\mathrm{kg} \mathrm{m}^{-1} \mathrm{~s}^{-1} \mathrm{~Pa}^{-1}\right.$, converted to $\mathrm{g} \mathrm{m}^{-1}$ day $\left.^{-1} \mathrm{kPa}^{-1}\right)$ was calculated based on the mean of four replicates at each time interval using formula (4) given by the standard:

$$
\mathrm{Wvp}=\frac{1}{A \Delta p /(\Delta G / \Delta t)-R A} \cdot t
$$

where $A$ the area of the open mouth of the test cup $\left(\mathrm{m}^{2}\right)$, $\Delta p$ the difference in water vapour pressure (1010.244 $\mathrm{Pa})$, $\Delta G / \Delta t$ the water vapour flux $\left(\mathrm{kg} \mathrm{s}^{-1}\right), R A$ the water vapour resistance of the air gap between the specimen and the salt solution $\left(4.80 \mathrm{E}+10 \mathrm{~m}^{2} \mathrm{~s} \mathrm{~g}^{-1}\right)$ and $t$ the thickness of the specimen $(\mathrm{cm})$.

\section{Pore structure}

Optical microscopy of thin-sections impregnated in blue resin was performed on wall 1 (W1) and wall 3 (W3) mortars using a Olympus BX43 microscope at 10× magnification with transmitted light.

\section{Experimental set-up of the test walls and repointing}

The experiment was designed to represent a low porosity masonry unit of dressed stones, as often found in southwest England, exposed to high intensity driving rainfall. For the purpose of enabling comparison between test walls and mortar joints the variables were minimised by not having a rubble core and by larger joints than usually found in ashlar dressing.

Five purpose-built test walls of $66 \mathrm{~cm}$ high, $62 \mathrm{~cm}$ wide and $15 \mathrm{~cm}$ deep were constructed (Fig. 1). The granite had a rough finish, also called a pick face [52], common in traditional and vernacular constructions, which also improves grip and adhesion of the mortar. The horizontal joints are continuous and all joints are between 1.5 and $2 \mathrm{~cm}$ thick to enable measurements. Each test wall was built with a different lime mortar (Table 1) to enable comparison of their response to driving-rain. The walls were cured for a 100 days in a sheltered laboratory 


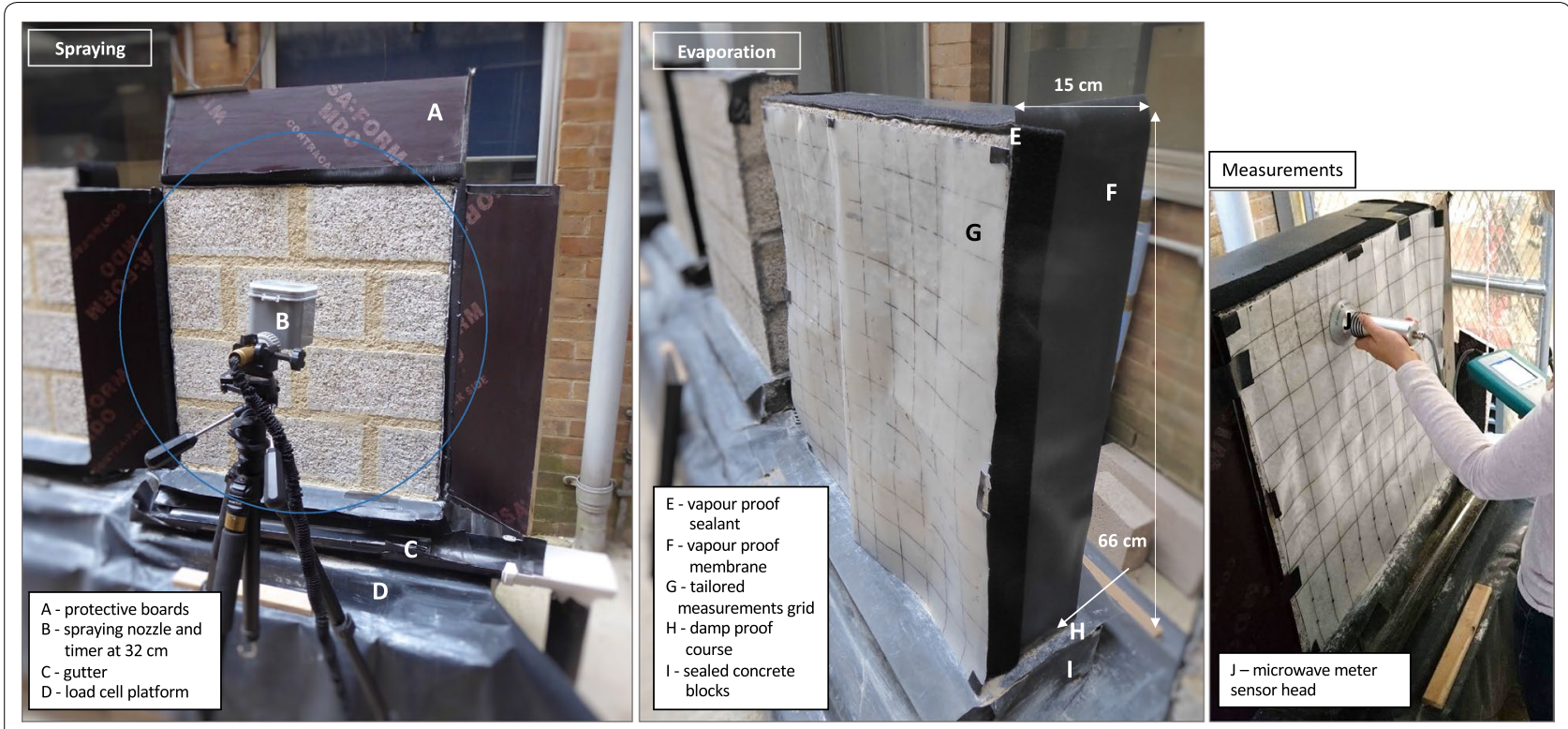

Fig. 1 Experimental set up during spraying and evaporation and drying, and location of the measurements. The protective board in plywood were preventing water from touching the other face of the wall and gutters were collecting the run-off water. The blue circle represents the area sprayed

area, protected from natural rain, wind and direct solar radiation.

After 7 months each test wall was repointed. The same mortar as previously used (Table 1) was used again in order to only assess the effect of repointing, inducing a greater compaction at the surface of the joints, and not of different materials. The new applied mortar was characterised to ensured consistency, with similar data obtained (Table 2). Mortar in joints was removed to $1.5 \mathrm{~cm}$ deep using a reciprocating machine with a diamond or tungsten cutting edge or hand tools if necessary (Fig. 2). Best practice was followed in mixing and applying the repointing mortar [22,53] (Fig. 2). The exact same artificial rain simulation, as explained in "Rain simulation and evaporation monitoring" section, followed by drying and evaporation monitoring, was repeated on each repointed wall.

\section{Rain simulation and evaporation monitoring}

Prior to spraying, the sides of the walls were sealed with vapour proof membrane (DPC, Visqueen) and vapour proof double-sided mastic sealing tape (Pavatape 12, NBT) to force evaporation through the main faces (Fig. 1).

Each wall was sprayed simulating a short intense and extreme rain spell in Devon. An intense spell of $5 \mathrm{~h}$ or less in duration, likely to occur once every 5 years for a wall orientated southwest was chosen from the weather data from Chivenor $\left(51^{\circ} 5^{\prime} 20^{\prime \prime} \mathrm{N}, 4^{\circ} 8^{\prime} 49^{\prime \prime} \mathrm{W}\right)$ [31, 54]. Rainfall was simulated using tap water from a cone low-flow

Table 2 WACC, open porosity and vapour permeability values of the mortar mixes applied in each wall

\begin{tabular}{|c|c|c|c|c|c|c|c|c|c|c|}
\hline & & & \multicolumn{2}{|c|}{ WACC $\left(g / \mathrm{m}^{2} \mathrm{~min}^{0.5}\right)(\mathrm{n}=6)$} & \multicolumn{2}{|c|}{$\begin{array}{l}\text { Water vapour } \\
\text { permeability } \\
\left(\mathrm{g} \mathrm{m}^{-1} \text { day }^{-1} \mathrm{kPa}^{-1}\right) \\
(\mathrm{n}=4)\end{array}$} & \multicolumn{2}{|c|}{$\begin{array}{l}\text { Open porosity }(\%) \\
\text { original mortar }(n=5)\end{array}$} & \multicolumn{2}{|c|}{$\begin{array}{l}\text { Open porosity }(\%) \\
\text { repointed mortar } \\
(n=5)\end{array}$} \\
\hline & & & Mean & SD & Mean & SD & Mean & SD & Mean & SD \\
\hline W1 & & & 282.22 & 10.94 & 2.328 & 0.248 & 20.33 & 0.21 & 21.46 & 0.02 \\
\hline W2 & $Q$ & & 192.37 & 3.87 & 1.876 & 0.062 & 23.32 & 0.25 & 21.20 & 0.23 \\
\hline W3 & $Q$ & $W A$ & 253.74 & 5.95 & 2.402 & 0.168 & 26.06 & 0.29 & 26.45 & 0.26 \\
\hline W4 & $Q$ & $W A$ & 275.57 & 23.85 & 1.938 & 0.102 & 25.65 & 0.19 & 24.28 & 0.12 \\
\hline W5 & $Q$ & WA & 197.86 & 6.96 & 2.111 & 0.137 & 21.74 & 0.63 & 23.92 & 0.56 \\
\hline
\end{tabular}

Q refers to Quicklime and WA to wood ash as indication of the compositions 


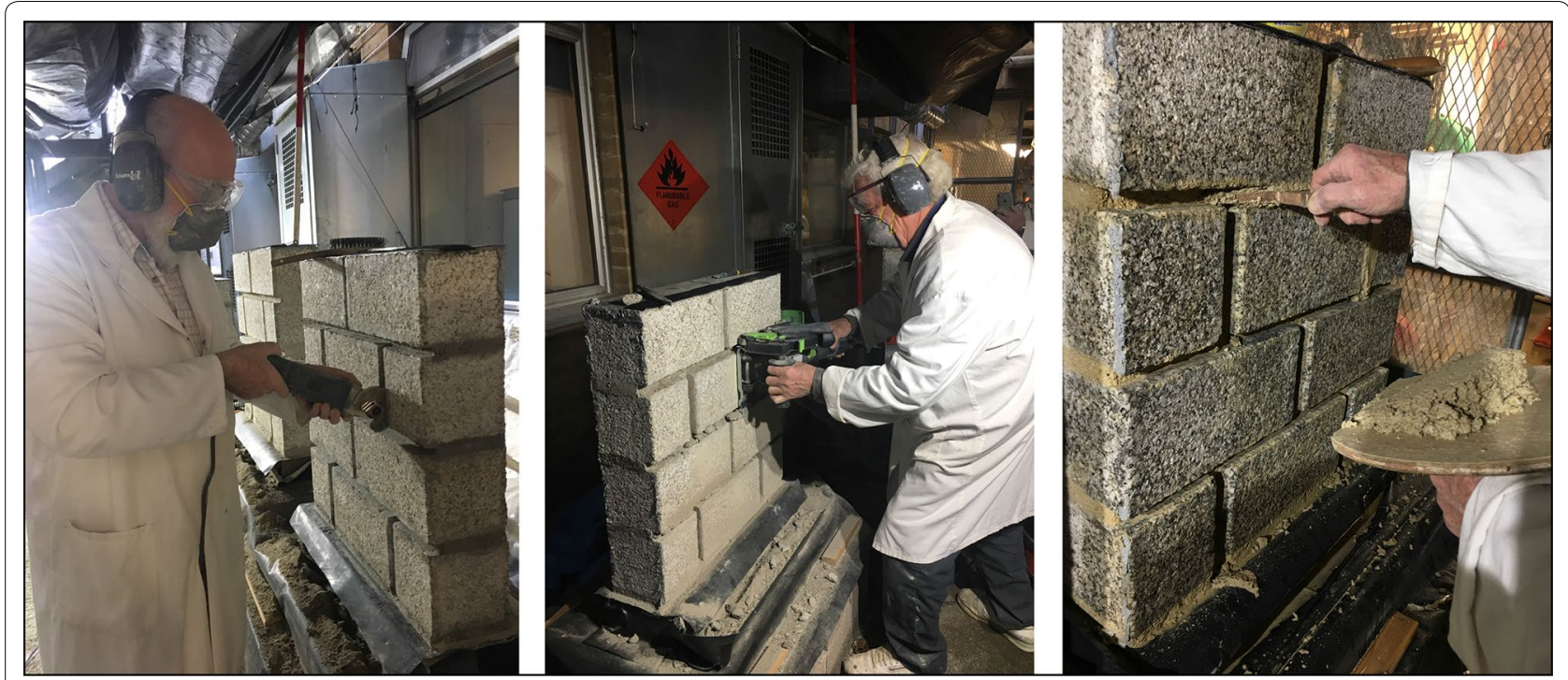

Fig. 2 Removal of the former mortar joints and repointing

nozzle with a uniform spray distribution. A stop-valve timer at a distance of $32 \mathrm{~cm}$ from the wall released $15 \mathrm{~s}$ of water every three minutes resulting in $10.32 \mathrm{~L} \mathrm{~m}^{-2}$ of simulated rain sprayed on the wall over a $3.25 \mathrm{~h}$ (Fig. 1). The timer was mounted on a tripod, so the height could be adjusted to be at the centre of the wall enabling an even distribution. In Fig. 1 the blue circle shows where the rain arrived on the face of the wall. The protective board in plywood were preventing water from touching the other face of the wall and a gutter was collecting the run-off water.

After the simulated rainfall, evaporation of each wall was monitored for 1 week (168 h) using a microwave moisture device (MOIST350B, hf sensor, Leipzig, DE). A tailored grid was designed for each wall ensuring that both mortar joints and granite were measured in a consistent pattern. The measuring points where the sensors were placed were approximately every $5 \mathrm{~cm}$ as shown on Fig. 1. Figure 3 summarises the several runs of spraying and evaporation monitoring for each wall, on the initial ones and once repointed. Overall the constant environmental conditions in the sheltered area to which both faces of the wall were exposed were a steady moderately cold but humid climate: $17 \pm 1{ }^{\circ} \mathrm{C}$ and $79 \pm 2 \% \mathrm{RH}$ for the initial test wall and mortar joints; and $17 \pm 4{ }^{\circ} \mathrm{C}$ and $64 \pm 3 \% \mathrm{RH}$ for drying monitoring after repointing; with negligible wind and no direct solar radiation.

Figure 4 shows the behaviour of the control wall (wall 1) after rain is simulated and during evaporation for every run. Wall 1 shows similar moisture level values and evaporation behaviour for each run, showing minimal variation between each run and little influenced of the slightly different environmental conditions. This enables good comparison of the other walls with the control wall at each run.

The microwave moisture device is a non-destructive and non-invasive technique, therefore suitable to use on historic buildings [33] and unaffected by the salt content of the building materials [55]. The MOIST350B works by producing electromagnetic waves reflected by the material surface [56]. The ratio of reflected and transmitted waves is called the reflection coefficient and is measured by the different reflection sensors of the device [56]. By multiplying the reflection coefficient with a fixed known factor the moisture meter gives a direct reading in a unitless "Moisture Index" (MI) in arbitrary units [57]. The $\mathrm{MI}$ is useful to assess relative change in moisture content over time but has not been calibrated against exact moisture content, therefore throughout the study it remains an indicator of moisture. In this study, two reflection sensors-heads were used to monitor the evaporation rate at near surface and depth: the R1M sensor, measuring up to $2-3 \mathrm{~cm}$, in the $900-1400 \mathrm{MI}$ range (referred here as "Surface"), and the PM sensor, measuring up to $20-30 \mathrm{~cm}$ in the range of 1300-2400 MI (referred here as "Depth") [55]. In dense stone like granite microwaves attenuates energy quickly, so it is considered that the reading from the PM sensor is up to $15 \mathrm{~cm}$ [58]. Because they are in different arbitrary ranges of values, the data from surface and depth are not directly comparable.

Measurements on all the mortar joints and granite units of one wall were then averaged over time and for both surface and depth to enable comparison between walls. In this study, the MI values have been normalised 


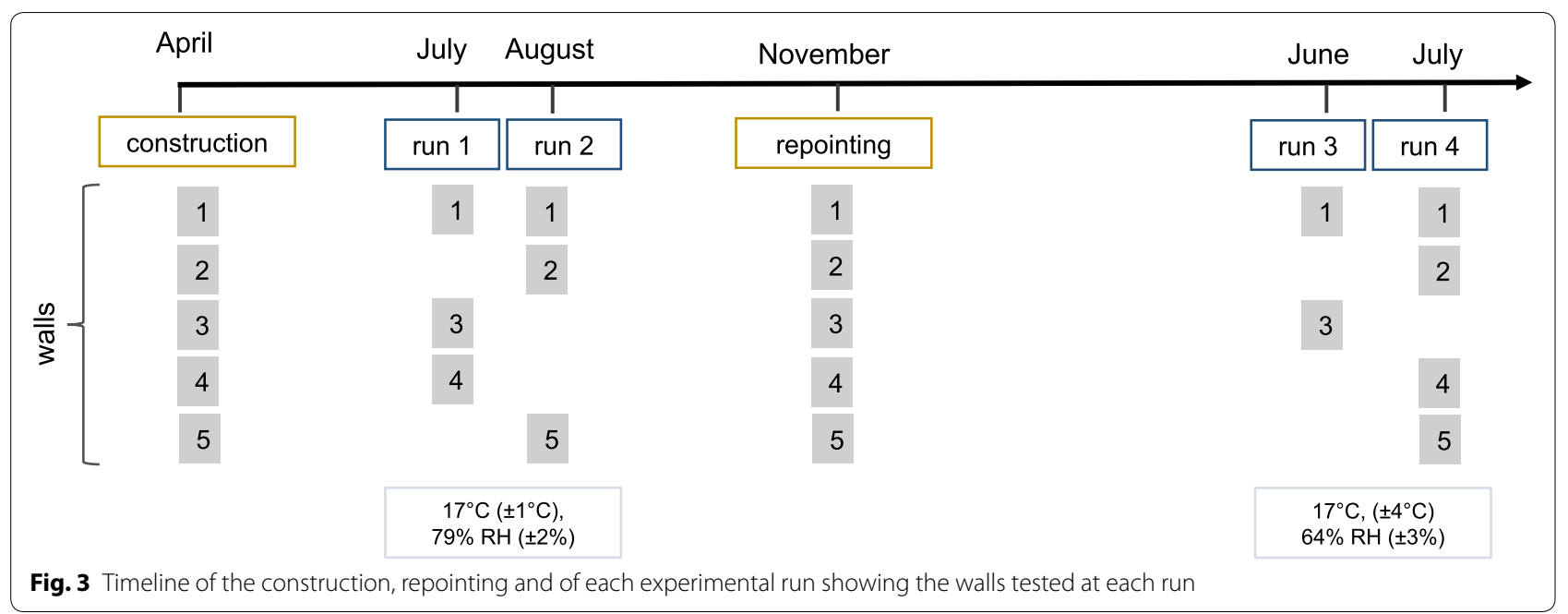

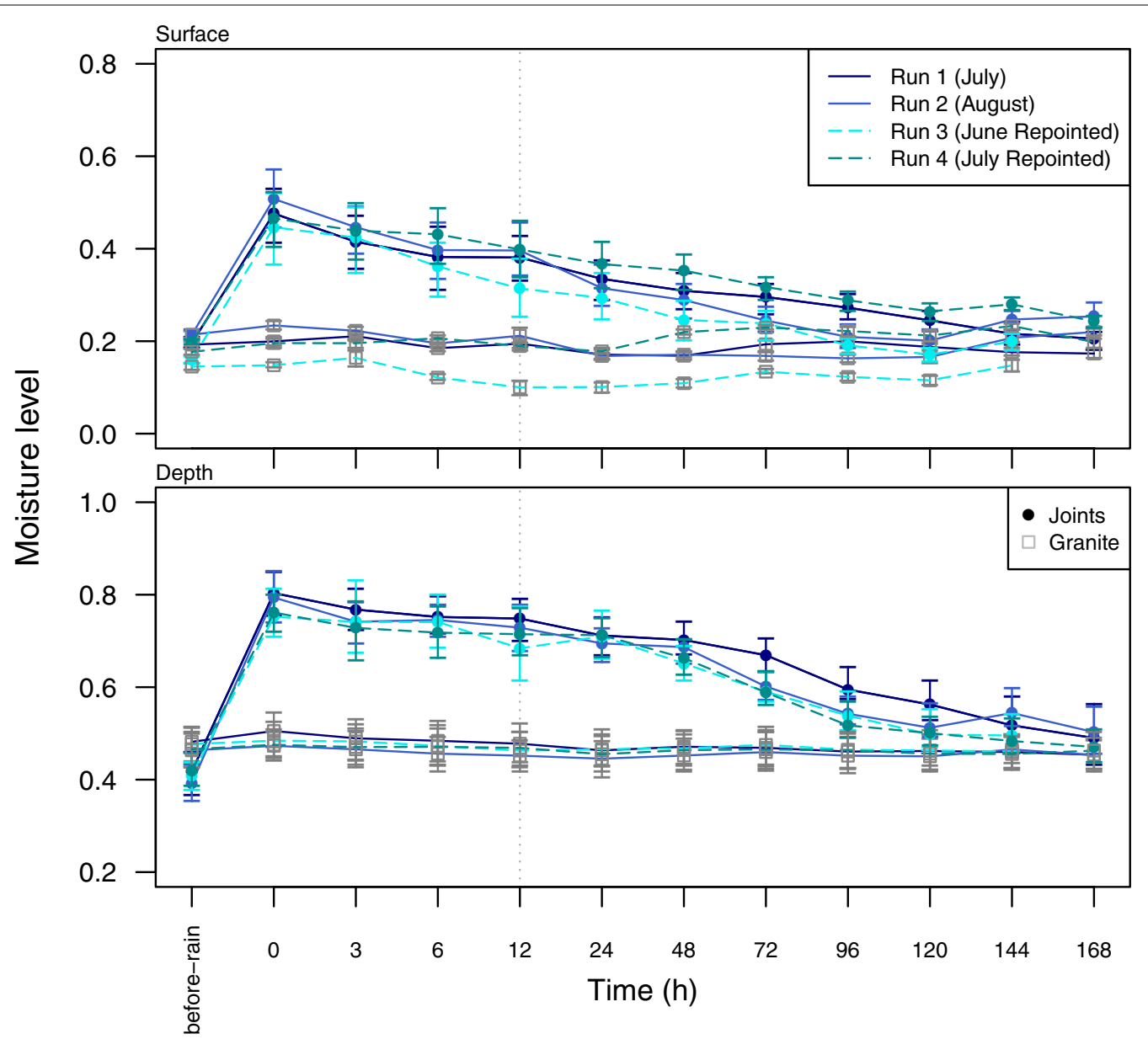

Fig. 4 Comparison of the control wall for each run of spraying and evaporation. The dashed line show the transition between time intervals: from every 3 and $6 \mathrm{~h}$ to every $12 \mathrm{~h}$ 
from 0 to 1 , as a 'relative' indicator, where higher data implies higher moisture levels. The difference of moisture level over time $(\Delta M)$ was calculated with the normalised data with the formula (5):

$$
\Delta M=M_{i}-M_{t}
$$

where $M_{i}$ the mean value of joints or granite at a specific time over $168 \mathrm{~h}$ and $M_{t}$, the mean value of joints or granite recorded "before rain".

The percentage change of moisture level between the data measured on the original test walls and after they were repointed was calculated with formula (6):

$$
\% \text { change } \mathrm{MI}=\frac{\Delta M R-\Delta M}{\Delta M} \times 100
$$

where $\Delta M R$, data from the repointed wall and $\Delta M$ data from the same wall (1), before repointing.

Few studies have used the microwave moisture meter on both mortar joints and masonry units and especially not for comparison of different mortar properties. The microwave moisture meter was chosen for this study for its ease of use and data handling. It has also been proven to give accurate results when calibrated against gravimetric measurements of different building stones for a range of water contents [59]. In addition, the device enables easy measurement within the thick masonry walls of historic buildings because it measures at different depths and access is only needed to one side of the wall.

\section{Results}

\section{Moisture movement through mortar joints}

Figure 5a, c shows normalised moisture levels over time at surface and at depth for all the joints in all five walls. Granite is not present in Fig. 5a, c as very few differences were seen. Figure 5b, b', d, d' show the differences of moisture level from the measurement taken before rain (formula 5), which could be considered as a relatively dry state (t0). Figure 6 presents the results of drying test of mortar samples placed in the same sheltered area. Figure 7 shows the visual appearance of the back of the wall after spraying and $3.25 \mathrm{~h}$ of drying.

Drying is the transfer of liquid water of the porous building materials to the surrounding environment [11]. Drying is therefore expected to depend on both the external conditions and on the materials properties [16]. It is well established that drying occurs in two stages [48]. Stage I drying is defined by the transport of liquid water to the surface of the materials followed by evaporation [60]. Until all liquid water has travelled to the surface, evaporation at the surface occurs at a constant rate under constant conditions. Stage I drying is therefore highly influenced by the boundary external conditions (temperature, RH and air flow) [60]. Stage II drying starts when transport of liquid water to the surface is no longer possible so that the rate of evaporation slows down [60]. Stage II drying is characterised by water vapour diffusion mechanisms and therefore influenced by the microstructure of the materials $[6,11]$.

At absorption and during the first $24 \mathrm{~h}$ of evaporation, at surface (Fig. 5a) and depth (Fig. 5c), all mortar joints show a similar order of moisture level (wall 2 having the lowest and wall 4 the highest), and start drying at the same time. After $24 \mathrm{~h}$, at depth, some test walls (specifically walls $3,4,5$ ) experience a more abrupt drying (lower moisture level) than the other walls.

The first $24 \mathrm{~h}$ of drying seems to correspond to stage I drying. Due to the constant external conditions $\left(17 \pm 1{ }^{\circ} \mathrm{C}\right.$ and $\left.79 \pm 2 \% \mathrm{RH}\right)$, mortar joints throughout the wall behave similarly up to $24 \mathrm{~h}$ of drying at surface (Fig. 5a) and depth (Fig. 5c). Stage I drying is mainly determined by the environmental boundary conditions and it has been demonstrated that as the RH increases, the rate of drying decreases [11].

Figures $5 \mathrm{~b}, \mathrm{~d}$ enable to see the capacity of absorption of the test walls from a 'dry' state ('before-rain') and the capacity of drying (as the curve goes back to a value close to the 0 line). As expected, mortar joints show higher absorption capacity (Fig. 5b, d) than the granite units (Fig. 5b', d'), showing that with the low-permeable granite, the joints are the location of most moisture movement, especially at depth. Figure 7 illustrates the expected behaviour, in which most water travels through the mortar joints-although the edges of the granite show signs of having absorbed little water.

Figure 5b' shows that the granite at surface is slightly affected by the rain events outside the sheltered area resulting in a more humid environment. Figure 5b' also illustrates that for some walls (walls $2,3,5$ ) the moisture level of the granite remains higher than at the start ('before-rain') throughout evaporation, whereas for walls 1 and 4 (red and blue lines), the moisture level of the granite quickly goes back to its initial value (represented by the 0 line) or even below. Although difficult to clearly identify this could give an indication of the action of mortar joints in absorbing moisture from the granite.

The walls in which mortar joints reach their 0 state or below show that the granite units also reach their initial value (Fig. 5b, walls 1 and 4), whereas walls in which mortar joints do not dry out as much (Fig. 5b, walls 2, 3 and 5), experience a granite unit that remains wetter (Fig. 5b'). Comparing Fig. 5a, b shows that mortar joints in wall 4 have likely absorbed moisture from the air before testing, therefore resulting in high moisture level (Fig. 5a) and capacity to dry below its starting point (0) (Fig. 5b). When stage II drying starts (after $24 \mathrm{~h}$ or later for some 


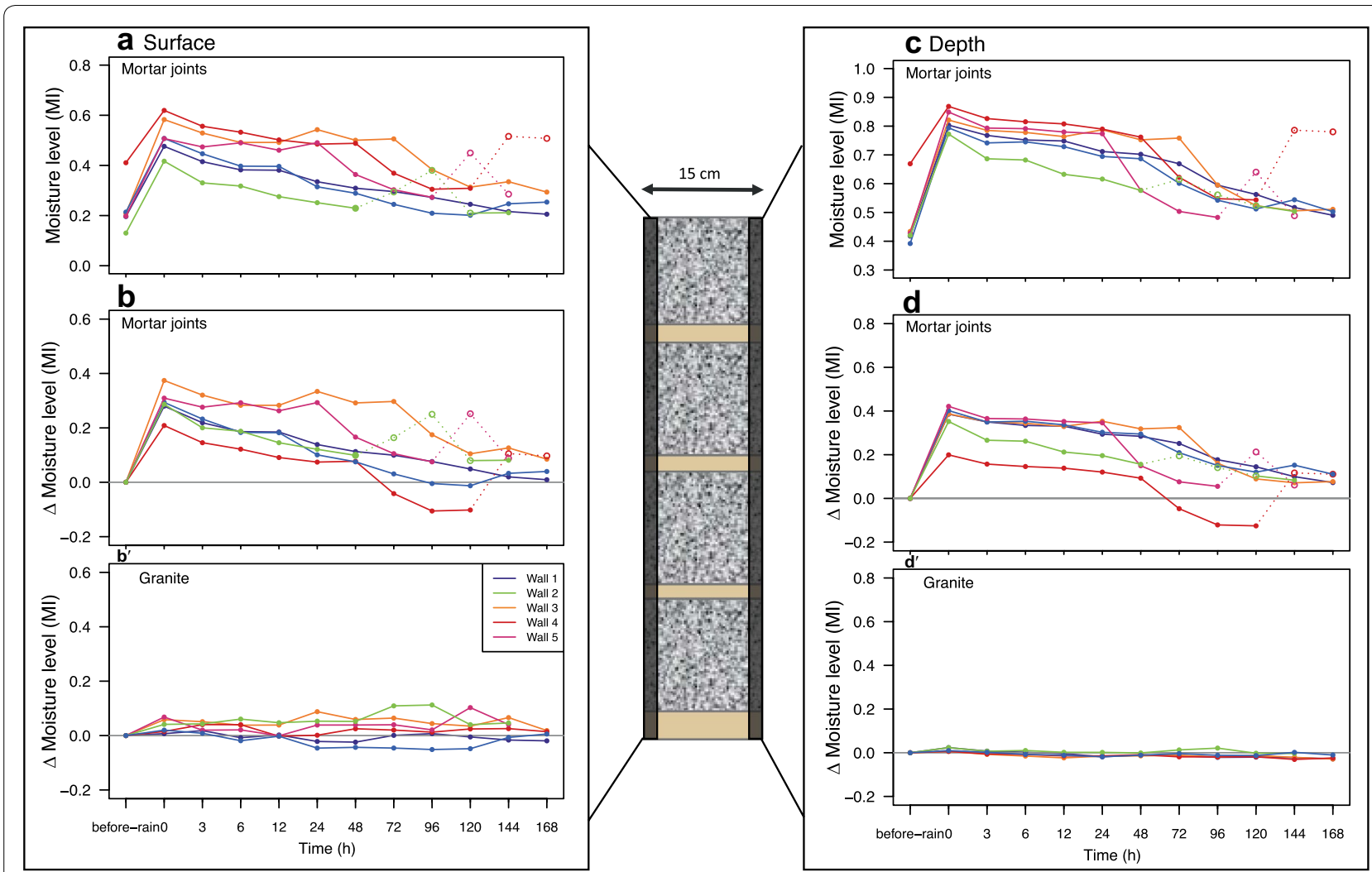

Fig. 5 Comparison of all mortar joints and granite units over time, based on their moisture level value at surface (a) and depth (c) and on the differences of moisture level (MI) since "before-rain" measurement at surface (b) and depth of the wall (d). Dashed lines and blank points represent the effect of high $\mathrm{RH}$ due to a rain event outside the sheltered area. The two blue lines for wall 1 represent the two runs of testing. $x$-axis represents different time intervals. to $\mathrm{h}=$ rain simulation and $\mathrm{Ml} 0(\mathbf{b}$ and $\mathbf{d})=\mathrm{Ml}$ value at start of the experiment. Data from surface and depth cannot be directly compared

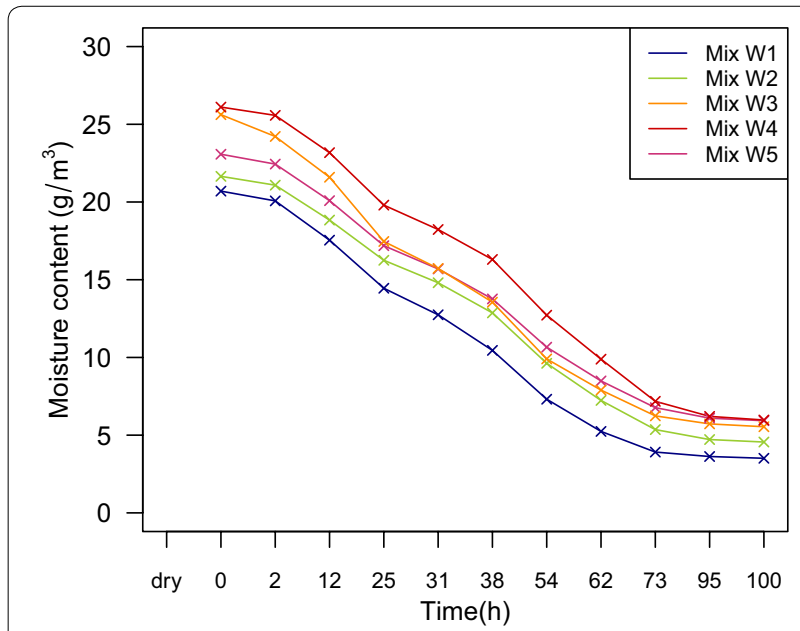

Fig. 6 Drying curves of laboratory mortar samples left to dry in the same sheltered area $(n=3)$ walls), the differences seen between each test wall may be explained in more details by material characteristics.

\section{Material comparison}

In Fig. 5a, c, higher value means higher moisture level. It is clear that mortar joints from the different walls show different moisture level both after rain at absorption $(t=0 \mathrm{~h})$ and during drying $(\mathrm{t}=3 \mathrm{~h}$ to $144 \mathrm{~h})$. As seen in Fig. 5a, mortar joints in wall 1 and especially wall 2 (which is made with mortar containing quicklime), show the lowest moisture level, whereas walls which have joints composed of mortars with wood ash (walls 3, 4, 5) show a higher moisture level. The same pattern is also seen in the drying curves of laboratory mortar samples (Fig. 6). Differences in absorption and drying of each wall can also be seen in Fig. 7 which shows the water egress through the back of the wall after spraying and $6 \mathrm{~h}$ of drying. Figure 8 compares the behaviours of pairs of individual walls (as explained in Table 1), using the same data set as presented in Fig. 5a, c. 

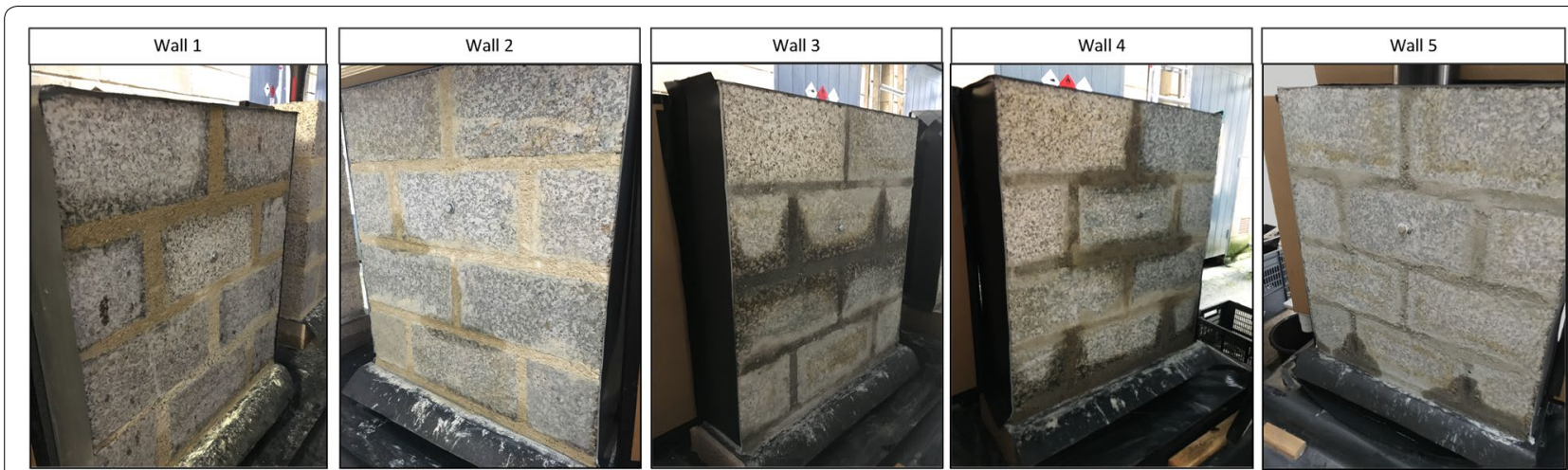

Fig. 7 Visual assessment of the back of the test walls after $3 \mathrm{~h}$ of spraying and $6 \mathrm{~h}$ of evaporation $(\mathrm{t}=6 \mathrm{~h}$ ). Water ingress visible through the bottom joint in all wall was not measured

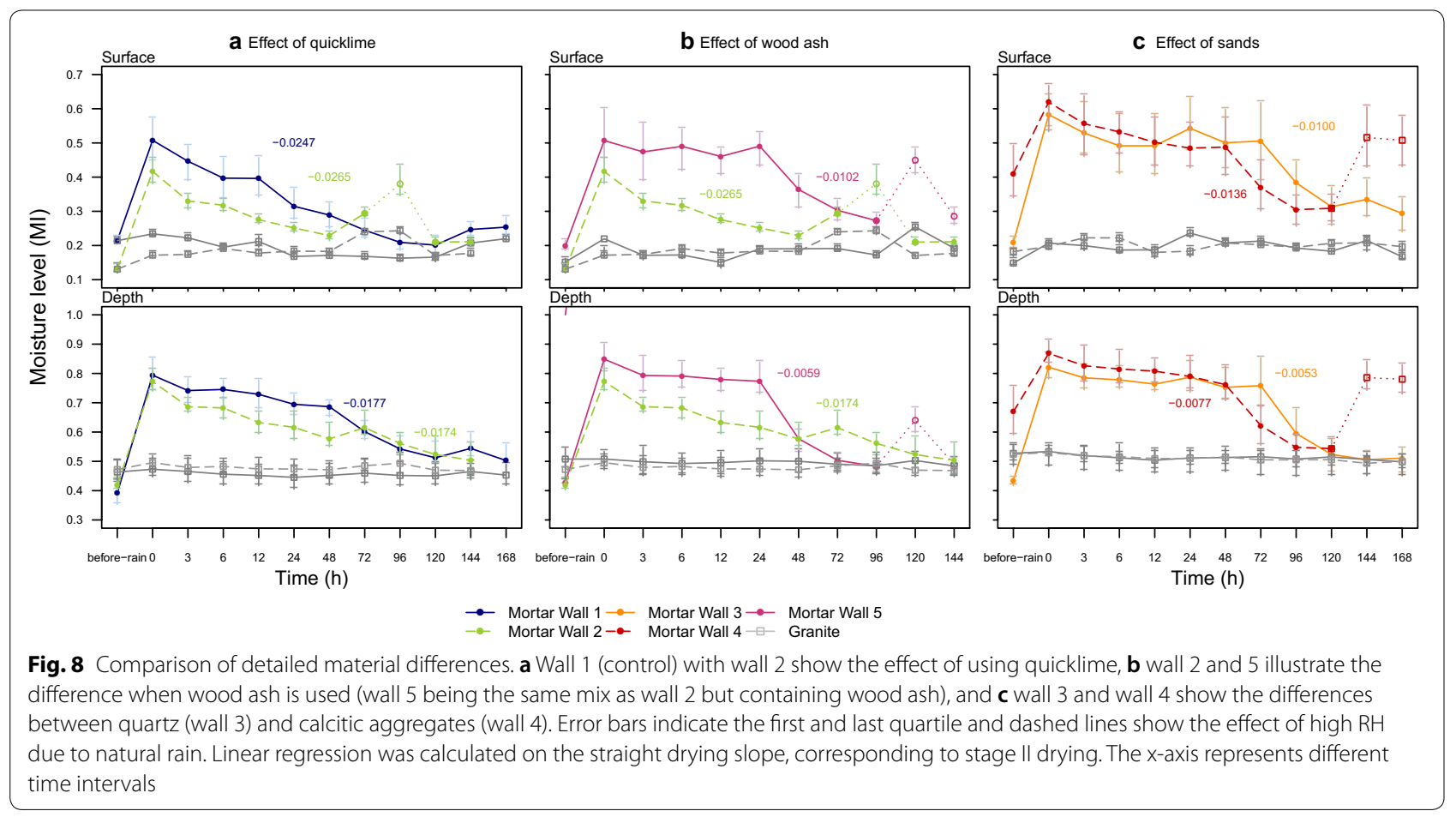

Figure 8a compares mortar joints made with NHL 3.5 (wall 1) and with gauged binder: NHL 3.5 and nonhydraulic quicklime (wall 2). At surface, mortars in wall 1 and 2 show similar drying patterns and little differences between their moisture level considering that wall 1 mortar has a higher MI level at $\mathrm{t}_{0}$. However, Fig. $5 \mathrm{~b}$ has also shown that joints in wall 2 never reached their 0 state ('before rain') and wall 2 mortar show the slowest WACC and lowest water vapour permeability (Table 2) and. It means that in wall 2 capillary saturation is reached slower than for mortar in wall 1 and that water vapour travels slower through mortar joints. The mortar would be less capillary active to absorb moisture from the surrounding masonry units. Because less water is absorbed by the material, the drying slope is quicker than mortar joints in wall 1 that has absorbed more moisture.

At depth, mortar joints in wall 1 have a slower drying rate than the joints in wall 2 (Fig. 5a, d). This can also be observed in Fig. 7 (wall 1), where the joints exhibit higher moisture level than the ones in wall 2. Mortar in wall 1 has indeed the higher capillary absorption rate (Table 2).

Gauging binder with quicklime appears to influence the pore structure of the mortar by reducing its capillarity and permeability as shown by Fig. 9, where capillary 


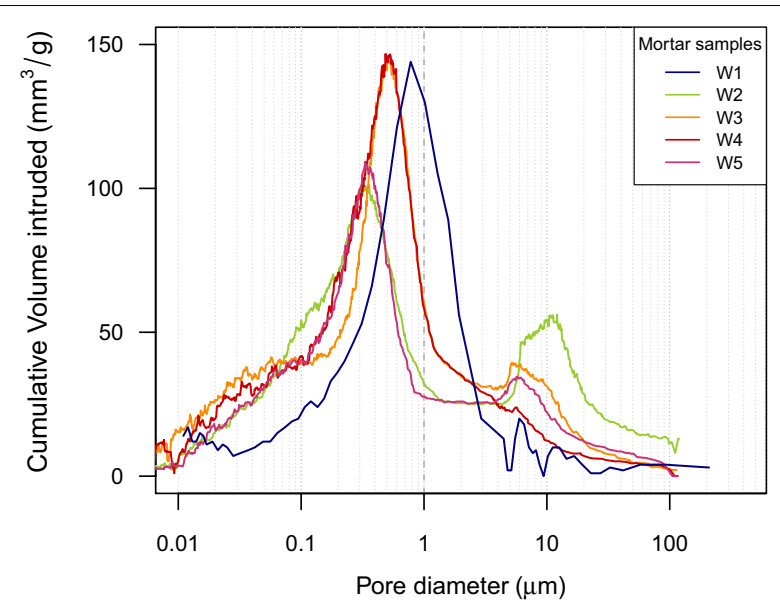

Fig. 9 Pore size distribution by MIP of mortar mixes. Dashed line represent the limit of capillary pores (1 to $1000 \mu \mathrm{m}$ )

pores are in lower proportion in the mortar of wall 2. Most of the pores of wall 2 mortar in the small capillary range, below $1 \mu \mathrm{m}$. Only pores from $1 \mathrm{~mm}$ to $1 \mu \mathrm{m}$ are practically relevant for capillary transport [7], which could explain the lower capillary coefficient (WACC) of the mortar in wall 2 (Table 2). The unimodal distribution of pores of wall 1 mortar could be explained by the higher water demand of the fresh NHL mix, which could have created larger pores [40].

Figure $8 \mathrm{~b}$ allows comparison between mortar mixes made with and without wood ash (e.g. wall 5 versus wall 2). Mortar with wood ash has been shown to have pores that are predominantly in the small capillary range, which can be seen for W3, W4 and W5 in Fig. 9. The mortar containing wood ash keeps a high moisture level longer after rain has been sprayed (between 24 and $72 \mathrm{~h}$ after the rain event) (Fig. 8b). When mortar joints remain wetter at the surface for longer periods, it could also show the movement of moisture within the joint: the liquid water moves through the wall until it reaches the surface and evaporates. Mortar joints with wood ash also demonstrate a relatively sudden drying response: over 3 days the moisture level value returns to 'before-rain' conditions. This results in two clear phases of drying. At depth (Figs. $5 \mathrm{~d}$ and $8 \mathrm{~b}$ ), the joints in wall 5 also remain wetter longer than those in wall 2 , but reach a lower moisture level after drying for 7 days. Despite having a high absorption at depth, no ingress of moisture from the back of the wall could be seen for wall 5 (Fig. 7).

Little difference of moisture level throughout drying and evaporation is seen between the use of different aggregates comparing wall 3 and 4 (Fig. 8c). However, joints in wall 3 , made with quartz sand, remain wetter longer as perhaps more moisture was absorbed. It is indeed the more porous and permeable of mortar mixes tested in laboratory (Table 2).

Comparing walls 3 and 4 with wall 5, which contains mixed aggregate, mortars made with one aggregate and with additives of wood ash, hold water longer (Fig. 8b, c). Calcitic aggregates have been shown to increase to proportion of pores bellow $1 \mu \mathrm{m}$ and give higher porosity [61], as shown by Fig. 9 for wall 4.

\section{Comparisons between joints}

Figure 7 already illustrated that for each test wall, the egress of moisture at the back of the wall was visually different depending on the joints and area of the wall. Figure 10 uses the same data set than Figs. 5a, c and 8 in order to compare over time, from absorption to evaporation, horizontal (beds) and vertical (perpends) joints, and all joints separately of walls 1 and 3 .

Vertical and horizontal mortar joints in wall 1 show differences in absorption $(t=0 h)$ and drying (from $t=3 h$ ), especially at depth (Fig. 10a). Vertical joints show higher moisture level, which is probably linked to workmanship and the difference in the pressure applied during construction [3]. Indeed, for wall 1, water egress at the back of the wall was especially visible at weak points present at the intersection between perpends and bed joints.

However, in all other test walls no significant differences are seen between perpends and beds, as joints in wall 3 illustrates (Fig. 10c). If there is little difference, as in walls 4 and 5 , vertical joints show a higher moisture level, and horizontal joints dry quicker. Vereecken has shown that bed joints are a preferred pathway for moisture [62], which here is only visible for the drying.

Figure 10b, d show that within a same wall differences between each perpend and bed joint can be noted. For walls 1 and 3, b3 joint (Fig. 10e) is drier at both surface and depth (Fig. 10b, d). In wall 4, b1 is the driest, as Fig. 7 (wall 4) shows. In walls 3 and 2, p6 is the driest joint. The other perpends show equal moisture level in all other walls, apart in wall 5 where p1 is much wetter, as Fig. 7 (wall 5 , bottom right joint) shows.

\section{After repointing each test wall}

Figure 11 shows moisture level data for the absorption and desorption curves of each of the original test walls, using both the same data set than Fig. 5a, c and data for the same walls repointed. Surface corresponds to the repointed part of the wall. Figure 12 represents the percentage changes of moisture level between the original wall and the repointed wall at absorption during the simulated rain and over evaporation and drying, calculated with formula (6). For the same rainfall simulation followed by drying, differences in the amount of moisture 

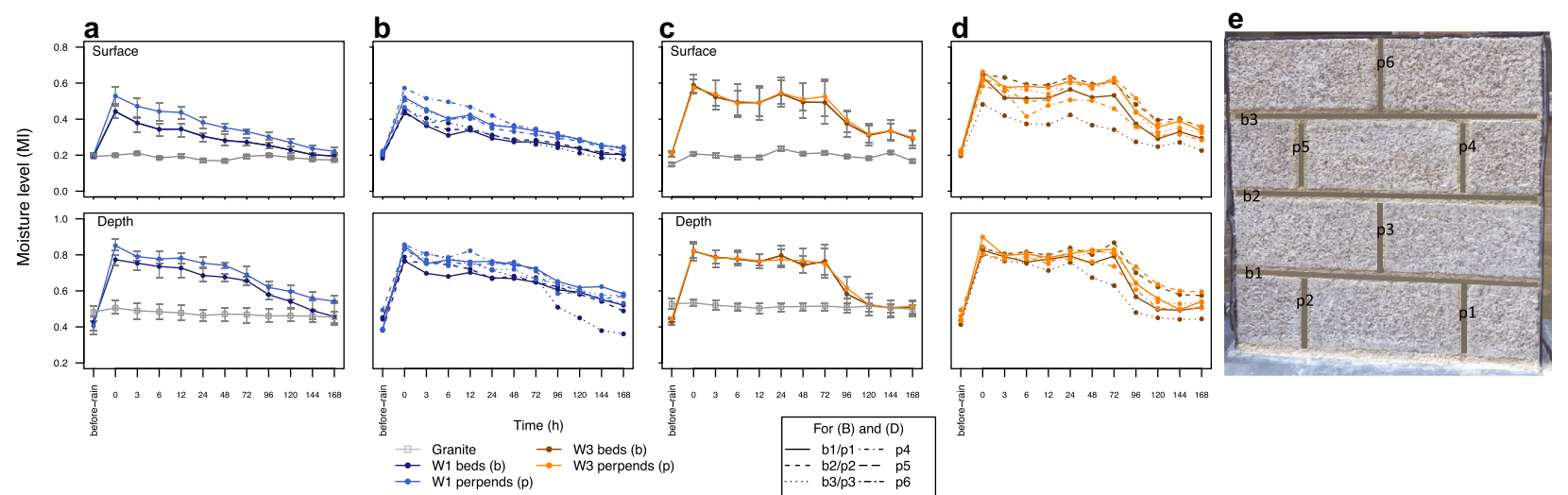

Fig. 10 Differences of drying curve between perpend joints ( $p$ ) and bedding joints (b) in wall 1 (a) and wall 3 (c) and between each joint of wall 1 (b) and wall 3 (d). e Indicates the location of each joint. Error bars indicate the first and last quartile. The $x$-axis represents different time intervals

level at absorption and during drying can be seen in mortar joints of all the test walls after repointing. Figure 11 shows that at both surface and depth, in each wall, the mortar joints follow a similar drying curve before and after repointing suggesting that the composition of the mortar is a major factor affecting the response of the joints.

Figure 12 clearly shows the differences between the original wall and the wall after it has been repointed. The moisture level right after the rain event $(t=0 h)$ is similar or lower for all mortar joints at surface and depth. More specifically, after drying for $24 \mathrm{~h}$, at the surface of mortar joints (i.e. the repointed parts), all but wall 2 and wall 5 (green and pink curves) show a lower moisture level after repointing (Fig. 12a). In walls 4 and 5, the granite at surface, remains with a higher moisture level throughout the test, whereas joints at depth have a lower moisture level after repointing. This could show that for these walls, the moisture stayed mainly at the surface of the test walls. Walls 1 and 3 (blue and orange lines) have overall a lower moisture level after repointing, due perhaps to more run off, so less water entering the joints, as shown in scenario 1 explained in the discussion. Looking at the pore structure of the mortar in wall 1 and 3, a denser matrix with fewer pores is visible on the repointing mortar (Fig. 14a, b) in comparison to the original mortar in beds and perpends joints of wall 1 where more shrinkage cracks and larger pores are visible (Fig. 14c, d).

At depth, again apart from wall 2 and 5, mortar joints also show a lower moisture level after repointing (Figs. 6, 11b). The lower moisture level after repointing at depth could be explained both by the effect of repointing and by the mortar in the joints being older (broadly 18 months after construction), where the porosity and capillary capacity could have decreased. It could also show that repointing helps the wall dry quicker. The lower moisture level measured on most mortar joints (Fig. 12b) is also visible on Fig. 13 by visual assessment, where minimal moisture egress can be seen on each wall compared to Fig. 7.

However, as shown by Fig. 12, mortar joints in wall 2 show the highest moisture absorption at the back of the wall, whereas it previously had the lowest WACC and MI level (Table 2, Fig. 7a). After repointing, mortar joints in each wall seems to behave slightly differently as to where the moisture moves and how the test wall dries out. Wall 2 has higher moisture level at surface until $48 \mathrm{~h}$, and higher at depth after $48 \mathrm{~h}$ which perhaps shows that the evaporation occurred mainly through the back of the walls.

\section{Discussion}

This study found that moisture movement in and out of a masonry test walls made of low-porous units clearly occurred though the mortar joints (Fig. 5). This was achieved by combining a simulation of an intense rainfall and monitoring of the drying response of different mortars near the surface and at depth over 7 days. This was undertaken in constant environmental conditions both after initial construction and after repointing.

Previous drying tests have shown that mortars dried under such high humidity $\left(15^{\circ} \mathrm{C}, 85 \% \mathrm{RH}\right)$ show a longer stage I drying [63]. This long stage I can also be seen in Fig. 6, where it last up until $73 \mathrm{~h}$ for laboratory samples under the same environmental conditions. A long stage I drying could be beneficial to allow the bulk of the masonry to fully dry out [6], which is here shown as the depth of the test wall dries out as much as the surface (Fig. 5c). It could also be argued that the effect of the increase of $\mathrm{RH}$ due to external conditions on walls 

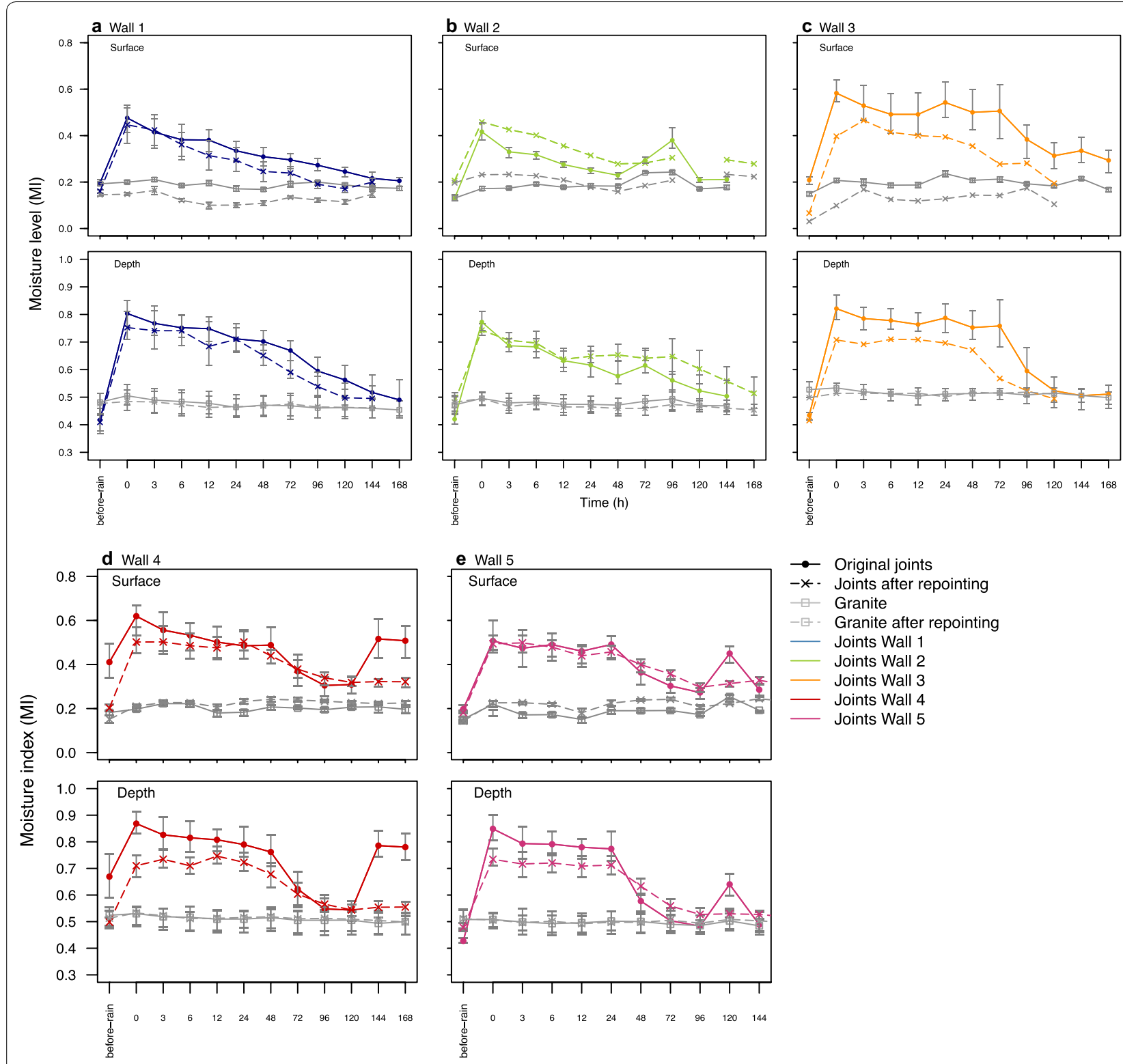

$\rightarrow$ Original joints

$-*$ - Joints after repointing

$\square$ Granite

- - - Granite after repointing

- Joints Wall 1

_ Joints Wall 2

- Joints Wall 3

J Joints Wall 4
Joints Wall 5

Time (h)

Fig. 11 Differences of moisture level (MI) of the mortar joints over time before and after being repointing. Error bars indicate the first and last quartile. The $x$-axis represents different time intervals

2 and 3 prevents the mortar joints from fully drying out (Fig. 5a, b). This shows that when mortar joints do not sufficiently dry to reach their initial state ('beforerain'), the granite units remain slightly wetter at surface (Fig. 5b, d, walls 2, 3, 5), illustrating the action of mortar in absorbing moisture from the masonry.

\section{The effect of workmanship}

The study found no clear differences between beds and perpends joints. Differences noticed in joints within each test wall were mainly attributed to their location in the test walls and to workmanship. The joints at the bottom of the wall are wetter likely due to more water from run-off and the joints at the top of the wall are drying having better evaporation, more exposed to the air circulation and being less affected by runoff. Weaker points at the intersection between beds and perpends and on the bottom joint of the test wall, where the mortar could be less compacted, showed quicker moisture ingress (Figs. 7, 10). In comparing the 


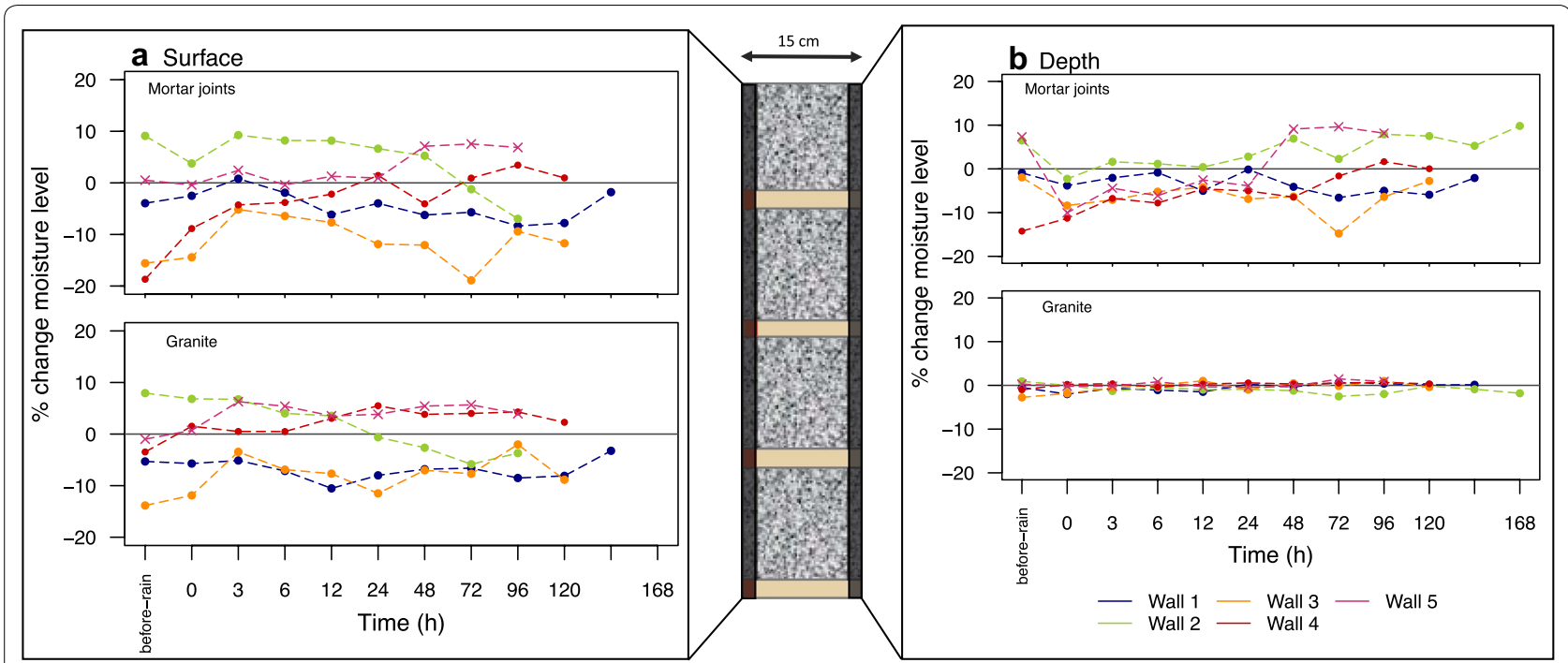

Fig. $12 \%$ change of moisture level value (MI) measured over time on joints and granite between the original walls (represented by the 0 value) and the repointed walls at surface $(\mathbf{a})$ and depth $(\mathbf{b})$. Negative changes show that the data measured on the repointed wall are lower than the original wall. $x$ axis represents different time intervals

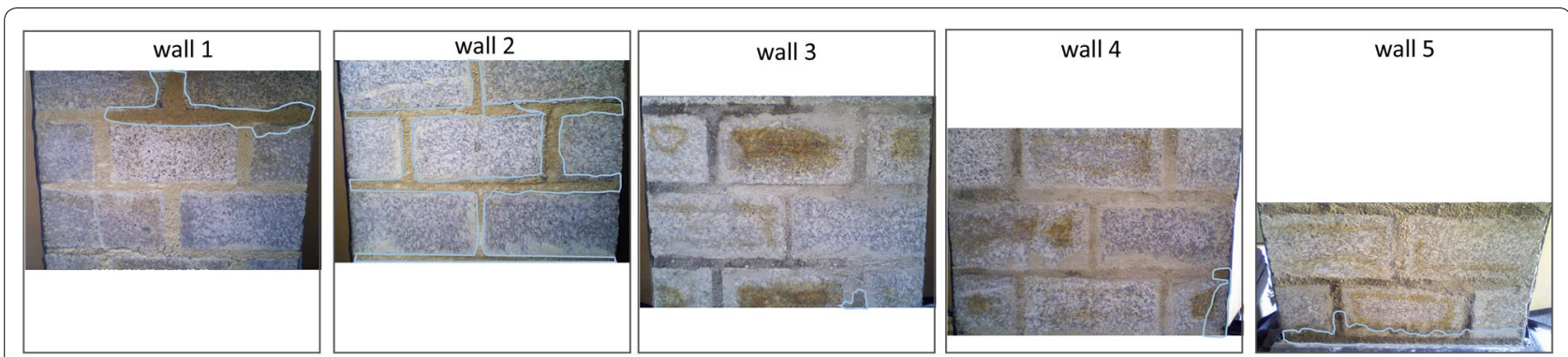

Fig. 13 Visual comparison of the back of the test walls once repointed, after spraying and after $6 \mathrm{~h}$ of evaporation ( $\mathrm{t}=6 \mathrm{~h}$ ). The blue boundaries highlight the egress of moisture. Missing parts of the walls are due to the location of the camera, but most of the moisture pattern are shown here

different test wall types in combination with laboratory mortar samples, the study also showed that all materials that were added influenced the absorption and drying performance of the mortars (Fig. 8).

\section{The importance of composition}

The same drying pattern is seen between the drying curves of laboratory mortar samples (Fig. 6) and the evaporation of mortar joints (Fig. 5a) showing that differences in the behaviour of mortar joints of each wall can be attributed to the different mortar compositions and not to environmental factors. In addition, once repointed, on the surface of the walls similar evaporation pattern as the original mortar are seen. This shows again that differences are based on the composition of the mortar joints and materials specificity: the key variable is wood ash, the type of sand does not have a significant influence.

Gauged NHL with quicklime (mainly seen in wall 2) exhibited lower overall moisture levels, which could minimise water ingress while maintaining a quick drying rate. Most pores within the mortar of wall 2 are in the small capillary range, below $1 \mu \mathrm{m}$. Only pores from $1 \mathrm{~mm}$ to $1 \mu \mathrm{m}$ are practically relevant for capillary transport [7], which could explain the lower capillary coefficient (WACC) of wall 2 mortar (Table 2). This could show that adding quicklime in mortar could help minimise water absorption and ingress through a masonry system.

Wood ash mortar holds moisture longer (Fig. 8b) and delayed the capillary absorption of mortar (Table 2). Previous research has shown the capacity of lime mortars made with wood ash to absorb high water content and to have an increased ability to dry out [35]. The fact that joints remain wetter longer at surface and depth could prevent the accumulation of water which can lead to further subsequent water ingress. When joints have reached saturation and cannot absorb more water, if another rain event occurs before they have started to dry out the water would likely run off the façade. 

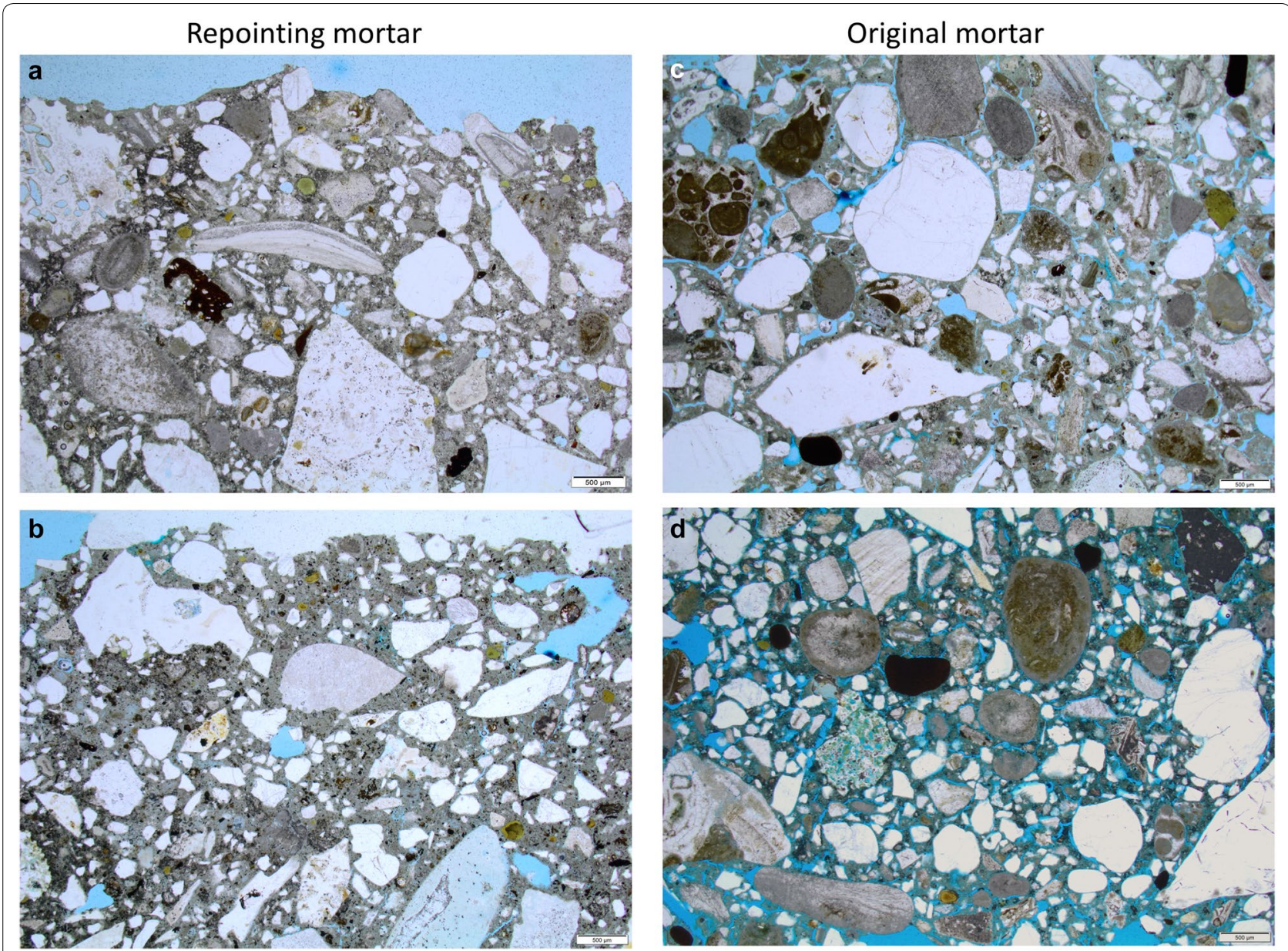

Fig. 14 Thin sections impregnated in blue resin seen under polarizing microscope showing the repointing mortar with the external surface of wall 1 (a) and wall 3 (b) and the original mortar in the horizontal joint (c) and vertical joint (d). $500 \mu \mathrm{m}$ scale bars

NHL mortar (wall 1) had a quick absorption and a lower evaporation, which made this mortar less suitable to help a masonry dry out (Fig. 8a). Figure 9 indeed shows that the mortar mix used in wall 1 (W1) has the most proportion of pores in the capillary range and is therefore highly capillary active.

Mixed aggregates mortars (primarily walls 2 and 5), perhaps by their bimodal pore size distribution (Fig. 9) of pores in the capillary and vapour permeability range, seems to be good at mitigating water ingress while showing a good capacity to dry out (Fig. 5). Indeed, materials with a high proportion of capillary pores will dry more efficiently under the same conditions and will also show high evaporation because the capillary drying regime is helping to dry out the masonry [64].

\section{From samples to test walls to real masonry}

The methodology and experimental design developed in this study enabled a confident comparison of the mortar joints in the five test walls during absorption and over drying. By combining best-practice workmanship, specific mortar design and rain simulation this research has developed a novel method to test the suitability of mortar for granite masonry and repointing mortar. Each wall was built identically, by the same mason, received the same amount of simulated rain and was tested under constant environmental conditions. This enabled confidence in the measured moisture levels when comparing the walls. Although differences in moisture level of different joints within one wall could be attributed to workmanship, those differences were minimal and did not alter the overall comparison between each mortar joints and test walls. The environmental conditions during drying monitoring of the repointed test walls had lower RH (by 15\%) which could partly explain the higher drying rate of the repointed walls. However, because the temperature was identical and the differences in RH low, the difference found after repointing can still be taken into account. 
The single-layer test walls were a clear and straightforward design to assess the response of a masonry system to driving rain, on the façade, at surface and at the depth. However, it is important to remember that larger masonry structures often consists of two single stone layers (often ashlar dressed) and a core made of rubble stone, mortar and both through stone and voids that are an easy conduit for liquid water to travel through the depth of the wall toward the interior of the building. The benefit of looking at two depths suggests the data could be used for real traditional masonry wall with a rubble core. The depth would then correspond to the core of the wall.

The microwave meter allowed straightforward monitoring of the drying and evaporation of the different materials in the test walls: mortar and granite at surface and depth over time. The MI calculated from microwave moisture data allows comparison between granite and mortar. Other electromagnetic devices (such as ground penetrating radar) were used in this study to measure the moisture level of the different building materials (not presented here) and found similar results in the comparative behaviour of mortar joints and granite units [65]. In addition, the drying curves found in laboratory experiments (Fig. 6) showed similar ranking of moisture levelwall 5 with the highest moisture content and walls 1 and 2 with the lowest. However, the drying in water content in $\mathrm{g} \mathrm{cm}^{-2}$ recorded in the laboratory cannot be directly compared to the MI values without calibration and the drying curves of the mortar samples are different to the curves recorded with MI values. In addition, MI values from the R1M (surface) and the PM (depth) sensors cannot be directly compared, which could lead to some confusion when analysing the data.

\section{Mechanical action of repointing and the suitability of the tested mortars for a dense masonry wall}

To reduce deterioration and internal dampness, ingress of moisture through the wall should be limited so that moisture stays at or near the outer surface. Repointing is one remedial treatment against dampness. This study investigated whether repointing could help mitigate moisture ingress and if so, how.

This study has shown that when the test walls were repointed, the depth of the wall absorbed less water than before repointing immediately following the simulated rain event (Fig. 12). If the amount of moisture throughout the depth of the wall is minimised once the wall is repointed, it could show that repointing could reduce the threat of water ingress and mitigate water ingress. It also shows that repointing could support quicker rates of drying, as less moisture enters the depth of the wall.
Two explanations could be given as why these differences of moisture level are seen, despite each test wall having been repointed using the same mortar as originally used for each. Indeed, the mortar removed and the mortar replaced have the same composition and therefore similar properties.

Firstly, repointing could work to both mitigate moisture ingress and help the surrounding masonry to dry out, because of the compaction that is required when applying the repointing mortar on the original bedding mortar. Previous research showed that mortars with intense compaction presented higher strength (5-9\% higher), lower open porosity ( $1-2 \%$ lower), and reduction of the proportion of large pores $(100-10 \mu \mathrm{m})$ and micro pores (diameter $<0.01 \mu \mathrm{m}[66]$. Such mortars are dominated by mesopores $(10-0.01 \mu \mathrm{m})$, situated mainly in the capillary range, therefore responsible for most of the movement of water. Similar observations are seen in repointed mortars in Fig. 14. This results in the repointing mortar in joint acting in resistance. This would explain why repointing mortar would do well in managing the movements of water during absorption and desorption.

Secondly, the greater ages of the original mortar left in the joints from initial construction (approximately 18 months since construction) could have decreased porosity and capillary capacity.

Comparison of each test wall between its two states: original and repointed, showed that all repointing mortar types could be suitable (Fig. 12). As Fig. 15 shows, this may be due to two proposed mechanisms. In scenario 1 , the repointing mortar absorbs slowly and holds on to water when saturation is reached, so that, although the evaporation is slower, no more liquid water can be absorbed into the mortar and vapour evaporation can take place. This type of repointing as in Scenario 1 would work under continuously wet environmental conditions that would prevent the mortar from drying out correctly. The repointing mortar would then hold on to water, preventing water accumulation and ingress, and encouraging run-off. In scenario 2, the repointing mortar is highly permeable with a quick absorption capacity and a high evaporation rate, facilitating its drying. Scenario 2 type of repointing would work well under many wetting and drying cycles due to rain events, as a mortar that dries quickly and absorb quickly would be able to perform well, mitigating moisture ingress through the wall.

Based on different specific environmental conditions or different wall expositions or building features that have different requirements (e.g. chimney, pinnacles vs masonry) some tested mortar may be more suitable than others. Based on Figs. 12 and 13, and on material characteristics, once repointed, walls 1,2 and 3 could correspond to scenarios 1 and walls 4 and 5 to scenarios 


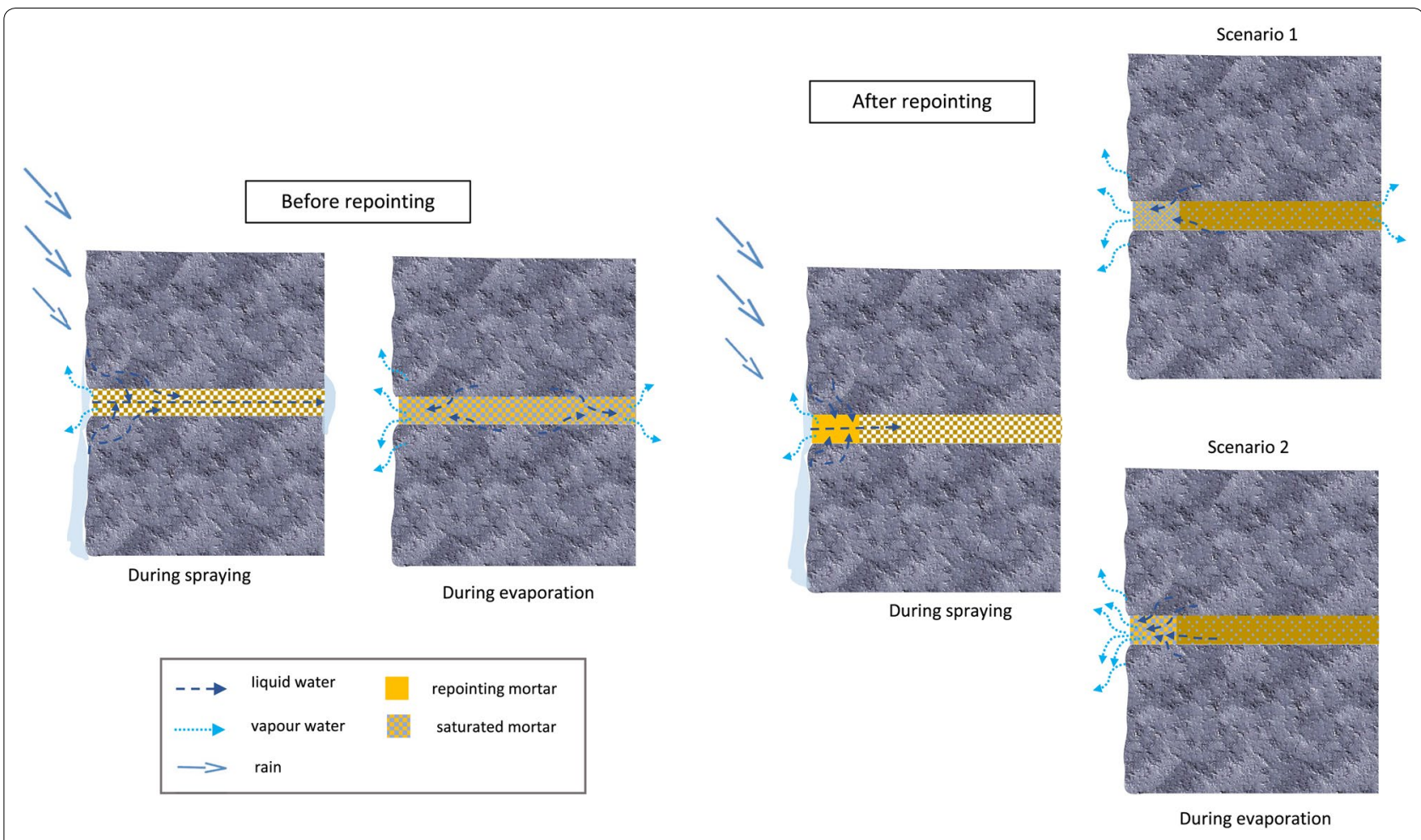

Fig. 15 Proposed schematic and simplified explanation of the movement of moisture between dense masonry units and lime mortar joints, during spraying and evaporation, and before and after repointing showing how and why repointing would help mitigate moisture ingress through a wall

2. This has important implications for consideration of repointing under specific environments or on different wall expositions, and for the role of workmanship in contributing to the functional role of repointing.

\section{Conclusions}

A comprehensive experiment was designed to assess the response to an intense rainfall event of different building materials within a specific masonry system-lime mortar and granite, at two levels-surface and depth, and two timeframes-at absorption and over a week of drying and evaporation. This study demonstrated that the experiment was suitable to enable comparison of different mortar joints types and of the test walls before and after repointing. Five main findings were made:

- The action of mortar in controlling moisture movement in the wall and absorbing moisture from the masonry was demonstrated.

- Differences of evaporation between horizontal and vertical joints in the same test wall were mainly attributed to their location in the test walls and workmanship.

- The selected composition of lime mortars, gauged with quicklime and wood ash additives gave mortar a decreased capillary absorption capacity and a good drying rate, making them suitable for use under very wet environmental conditions (i.e. mortars in walls 2 and 4), while mixed aggregate increased the capillary absorption.

- This study has shown that when test walls were repointed, the depth of the wall absorbed less water than before repointing.

- Repointing is therefore a suitable conservation solutions to mitigate the threat of water ingress and increase the drying capacity.

- At the surface, repointed wall behaved differently, and two scenarios were identified, each suitable for slightly different environmental conditions or wall expositions:

Scenario 1, repointing mortar holds on to water when saturation is reached, so that no more liquid water can be absorbed into the mortar and vapour evaporation is favoured-suitable for under continuously wet environmental conditions, preventing water accumulation and ingress. Scenario 2, the repointing mortar has a high evaporation rate, facilitating its drying, so moisture stays mainly at the surface-suitable for mortar under 
many wetting and drying cycles as mortar that dries quickly and absorb slowly.

These findings have important practical implications when considering both the design of mortar for dense and low-porous masonry and of repointing, and when evaluating the performance and role of repointing mortar.

\section{Acknowledgements}

The authors would like to specifically thanks Bill Revie and Colin Burns for building the test walls to best-practice and providing expert advice. Specific thanks also go to the Facilities team at the School of Geography and the Environment, Alex Black, Joe Milkovic and Armpen Kristo, for their help preparing and monitoring the sheltered area for the test walls, and to Alison Henry, Elisabeth Laycock and Simon Cartlidge for their advice in designing the test walls.

\section{Authors' contributions}

LF: Designed the experiments, contributing to building the test walls and making laboratory samples, collected all the data, analysed the data and wrote the paper. SAO: Co-designed the experiment method, gave expert advice on the use of MOIST350B, created the script to read and extract the MOIST530B data, helped with the collection and analysis of the data and reviewed the paper. CW: provided funding for building the test walls and expert advice on building test walls for laboratory experiments. MOD: provided guidance of the suitable stone to use for the wall and advise of on-site issues with rainfall. HV: helped defined the aims and scope of the study and coordinated the different authors. All authors read and approved the final manuscript.

\section{Funding}

This research was supported by the UK EPSRC grant for the Centre for Doctoral Training in Science Engineering in Arts, Heritage and Archaeology (SEAHA) (grant number EP/L016036/1) and by Historic England.

\section{Availability of data and materials}

The datasets used and analysed during the current study are available from the corresponding author on reasonable request.

\section{Competing interests}

The authors declare that they have no competing interests.

\section{Author details}

${ }^{1}$ School of Geography and the Environment, University of Oxford, Oxford OX1 3QY, UK. ${ }^{2}$ Historic England, Cannon Bridge House, 25 Dowgate Hill, London EC4R 2YA, UK. ${ }^{3}$ The Churches Conservation Trust, 8 All Saints Street, London N1 9RL, UK.

Received: 5 December 2018 Accepted: 25 May 2019

Published online: 10 June 2019

\section{References}

1. Gething B. Design for future climate; 2010.

2. English Heritage. Damp Towers Conference. In Exeter, Devon; 2013.

3. Laycock EA, Wood C. Understanding and controlling the ingress of driven rain through exposed, solid wall masonry structures. Geol Soc Spec Publ. 2014;391(1):175-91. https://doi.org/10.1144/SP391.1.

4. Oliver AC. Dampness in buildings. 2nd ed. Oxford: Blackwell Science Ltd; 1997

5. Erkal A, D'Ayala D, Sequeira L. Assessment of wind-driven rain impact, related surface erosion and surface strength reduction of historic building materials. Build Environ. 2012;57:336-48. https://doi.org/10.1016/j. buildenv.2012.05.004

6. Pender R, Ridout B, Curteis T. Practical building conservation. Building environment. London: English Heritage; 2014.

7. Siegesmund S, Dürrast H. Physical and mechanical properties of rocks. In: Siegesmund S, Snethlage R, editors. Stone in architecture-properties, durability. Springer: Berlin; 2014. p. 97-224.
8. Abuku M, Janssen H, Roels S. Impact of wind-driven rain on historic brick wall buildings in a moderately cold and humid climate: numerical analyses of mould growth risk, indoor climate and energy consumption. Energy Build. 2009;41(1):101-10. https://doi.org/10.1016/j.enbui ld.2008.07.011.

9. Brimblecombe P, Grossi CCM. Damage to buildings from future climate and pollution. APT Bull J Preserv Technol. 2007;38(2):13-8. https://doi. org/10.2307/40004714.

10. Hughes P, Society for the Protection of Ancient Buildings. The need for old buildings to "breathe". London: Society for the Protection of Ancient Buildings; 1987.

11. Hall C, Hoff WD, Nixon MR. Water movement in porous building materials-VI. Evaporation and drying in brick and block materials. Build Environ. 1984;19(1):13-20. https://doi.org/10.1016/0360-1323(84)90009-х.

12. Kenneth T. Masonry walls: specification and design. Oxford: ButterworthHeinemann; 1995.

13. Hughes J, Young M, Laing S. Mortars for pointing granite: a feasibility study. KTTBE award; 2008.

14. Young ME. Dampness penetration problems in granite buildings in Aberdeen, UK: causes and remedies. Constr Build Mater. 2007;21(9):1846-59. https://doi.org/10.1016/j.conbuildmat.2006.05.027.

15. Laurie LP, Milne J. The evaporation of water and salt solutions from surfaces of stone, brick and mortar. J Franklin Inst. 1927;204(5):692-3. https:// doi.org/10.1016/S0016-0032(27)91699-8.

16. Wiggins DE. Lime Mortar and the sacrificial protection of heritage masonry. Glasgow: Glasgow Caledonian University; 2015.

17. Hall C, Hamilton A, Hoff WD, Viles HA, Eklund JA. Moisture dynamics in walls: response to micro-environment and climate change. Proc R Soc A Math Phys Eng Sci. 2011;467(2125):194-211. https://doi.org/10.1098/ rspa.2010.0131.

18. Orr SA, Young M, Stelfox D, Curran J, Viles H. Wind-driven rain and future risk to built heritage in the United Kingdom: novel metrics for characterising rain spells. Sci Total Environ. 2018;640-641:1098-111. https://doi. org/10.1016/j.scitotenv.2018.05.354.

19. Child M. Discovering churches and churchyards : a guide to the architecture of English parish churches from Anglo-Saxon times to 1900 Churches and churchyards. Princes Risborough: Shire; 2007 (Discovering series).

20. Hughes JJ. RILEM TC 203-RHM: repair mortars for historic masonry, The role of mortar in masonry: an introduction to requirements for the design of repair mortars. Mater Struct. 2012;45(9):1287-94. https://doi. org/10.1617/s11527-012-9847-9.

21. van Hees R. RILEM TC 203-RHM: repair mortars for historic masonry. Mater Struct. 2012;45(9):1295-302. https://doi.org/10.1617/s11527-012-9917-z.

22. Pickles D, Henry A, Stewart J, McCaig I. Repointing brick and stone walls: guidelines for best-practice; 2017

23. Newman AJ. Workmanship, rain penetration, and cavity wall insulation. In: International masonry society papers from conference Proceedings. Whyteleafe, Surrey: International Masonry Society; 1989. p. 58-61.

24. Ashurst J, Dimes FG. Conservation of building and decorative stone. Orford: Butterworth-Heinemann; 1998.

25. Groot CJWP, Gunneweg JTM. The influence of materials characteristics and workmanship on rain penetration in historic fired clay brick masonry. Heron. 2010;55(2):141-54

26. Wood C. Damp towers. Conserv Bull. 2012;69:14-5.

27. Forster A, Carter K. A framework for specifying natural hydraulic lime mortars for masonry construction. Struct Surv. 2011;29(5):373-96. https:// doi.org/10.1108/02630801111182411.

28. Mosquera MJ, Benítez D, Perry SH. Pore structure in mortars applied on restoration effect on properties relevant to decay of granite buildings. Cem Concr Res. 2002;32(12):1883-8. https://doi.org/10.1016/s0008 -8846(02)00887-6.

29. O'Brien PF, Bell E, Pavia Santamaria S, Boyland P, Cooper TP. Role of mortars in the decay of granite. Sci Total Environ. 1995;167(1-3):103-10. https ://doi.org/10.1016/0048-9697(95)04573-J.

30. Sass $O$, Viles HA. Wetting and drying of masonry walls: 2D-resistivity monitoring of driving rain experiments on historic stonework in Oxford UK. J Appl Geophys. 2010;70(1):72-83. https://doi.org/10.1016/j.jappg e.2009.11.006. 
31. Orr SA, Viles H. Characterisation of building exposure to wind-driven rain in the UK and evaluation of current standards. J Wind Eng Ind Aerodyn. 2018;180:88-97. https://doi.org/10.1016/j.jweia.2018.07.013.

32. Rirsch E, Zhang Z. Rising damp in masonry walls and the importance of mortar properties. Constr Build Mater. 2010;24(10):1815-20. https://doi. org/10.1016/j.conbuildmat.2010.04.024.

33. Válek J, Kruschwitz S, Wöstmann J, Kind T, Valach J, Köpp C, et al. Nondestructive investigation of wet building material: multimethodical approach. J Perform Constr Facil. 2010;24(5):462-72. https://doi. org/10.1061/(ASCE)CF.1943-5509.0000056.

34. Maurenbrecher AHP, Suter GT, Trischuk K, Fontaine L. Contribution to pointing mortar durability. In: International RILEM workshop on historic mortars characteristics tests Paisley, Scotland, 12th-14th May 1999; 2000. p. 361-70.

35. Fusade L, Viles H, Wood C, Burns C. The effect of wood ash on the properties and durability of lime mortar for repointing damp historic buildings. Constr Build Mater. 2019;212:500-13. https://doi.org/10.1016/j.conbu ildmat.2019.03.326.

36. Henry A, Stewart J. Mortars, renders \& plasters (practical building conservation). Farnham: Ashgate Pub Co; 2012

37. Lanas J, Pérez Bernal JL, Bello MA, Alvarez Galindo Jl. Mechanical properties of natural hydraulic lime-based mortars. Cem Concr Res. 2004;34(12):2191-201. https://doi.org/10.1016/j.cemconres.2004.02.005.

38. Maravelaki-Kalaitzaki P, Bakolas A, Karatasios I, Kilikoglou V. Hydraulic lime mortars for the restoration of historic masonry in Crete. Cem Concr Res. 2005;35(8):1577-86. https://doi.org/10.1016/j.cemconres.2004.09.001.

39. Allen G, Allen J, Elton N, Farey M. Hydraulic lime mortar for stone, brick and block masonry: a best practice guide. Shaftesbury: Rouledge, Donhead Publishing; 2003.

40. Banfill PFG, Forster AM. A Relationship between hydraulicity and permeability on hydraulic lime. In: InternationI RILEM workshop on historic mortars characteristics tests; 1999. p. 173-83.

41. Forster A. Hot-lime mortars: a current perspective. J Archit Conserv. 2004. https://doi.org/10.1080/01823328908726936.

42. Artis R. Specifying hot-mixed lime mortars-Technical Paper 28. Edinburgh: Historic Environment Scotland; 2018.

43. Henry A. Hot-mixed mortars: the new lime revival. Context Institure Hist Build Conserv. 2018;154(May):30-3.

44. ASTM. E2260-03. Standard guide for repointing (Tuckpointing) historic masonry, vol. 88. West Conshohocken: ASTM; 2012

45. British Standard Institution. BS EN 1015-3:1999 Methods of test for mortar for masonry. Determination of consistence of fresh mortar (by flow table), vol. 3. London: British Standard Institution; 1999.

46. Derluyn $\mathrm{H}$, Janssen $\mathrm{H}$, Carmeliet J. Influence of the nature of interfaces on the capillary transport in layered materials. Constr Build Mater. 2011;25(9):3685-93. https://doi.org/10.1016/j.conbuildmat.2011.03.063.

47. British Standard Institution. BS EN 1936:2006 Natural stone test methods. Determination of real density and apparent density, and of total and open porosity, vol. 3. London: British Standard Institution; 2006.

48. Hall C, Hoff WD. Water transport in brick, stone and concrete (2015). Routledge: CRC Press, Taylor \& Francis; 2009.

49. British Standards Institution. BS EN 1015-18:2002-Methods of test for mortar for masonry - determination of water absorption coefficient due to capillary action of hardened mortar, vol. 3. London: British Standards Institution; 2006.

50. British Standard Institution. BS EN 1925:2000-Natural stone test methods $Đ$ Determination of water absorption coefficient by capillarity. London: British Standard Institution; 1999.
51. British Standards Institution. BS EN 1015-19:1999 Methods of test for mortar for masonry-Part 19: determination of water vapour permeability of hardened Renderinf and plastering mortars. London: British Standards Institution; 1999.

52. Purchase WR. Practical masonry: a guide to the art of stone cutting. London: Routledge; 2015

53. Maurenbrecher P. RILEM TC 203-RHM: repair mortars for historic masonry. Requirements for repointing mortars for historic masonry. Mater Struct. 2012;45(9):1295-302. https://doi.org/10.1617/s11527-012-9917-z.

54. Pérez-Bella JM, Domínguez-Hernández J, Rodríguez-Soria B, Del Coz-Díaz JJ, Cano-Suñén E. Estimation of the exposure of buildings to driving rain in Spain from daily wind and rain data. Build Environ. 2012;57:259-70. https://doi.org/10.1016/j.buildenv.2012.05.010.

55. Lataste J-F, Göller A. Microwave Reflection. In: Lars-Olof N, editor. Methods of measuring moisture in building materials and structures-stateof-the-art report of the RILEM technical committee 248-MMB. Springer International Publishing; 2018. p. 123-40.

56. Göller A. Microwave scanning technology for material testing. In: Proceedings of the 9th European conference on NDT, DGZfP-proceedings $\mathrm{BB} ; 2006$.

57. Orr SA, Young M, Stelfox D, Leslie A, Curran J, Viles H. An `isolated diffusion' gravimetric calibration procedure for radar and microwave moisture measurement in porous building stone. J Appl Geophys. 2019;163:1-12. https://doi.org/10.1016/j.jappgeo.2019.02.003.

58. BSI. BS EN 16682:2017 Conservation of cultural heritage-methods of measurement of moisture content, or water content, in materials constituting immovable cultural heritage. London: British Standard Institution; 2017.

59. Orr SA, Young M, Stelfox D, Leslie A, Curran J, Viles H. An, "isolated diffusion" gravimetric calibration procedure for radar and microwave moisture measurement in porous building stone. J Appl Geophys. 2019;163:1-12. https://doi.org/10.1016/j.jappgeo.2019.02.003.

60. British Standards Institution. BS EN 16322:2013 Conservation of cultural heritage - test, methods - determination of drying properties. London: British Standards Institution; 2013.

61. Lanas J, Alvarez J. Masonry repair lime-based mortars: factors affecting the mechanical behavior. Cem Concr Res. 2003;33(11):1867-76. https:// doi.org/10.1016/S0008-8846(03)00210-2.

62. Vereecken $\mathrm{E}$, Roels S. Hygric performance of a massive masonry wall: how do the mortar joints influence the moisture flux? Constr Build Mater. 2013;41:697-707. https://doi.org/10.1016/j.conbuildmat.2012.12.024.

63. Fusade L, Viles $H$. A comparison of standard and realistic curing conditions of natural hydraulic lime repointing mortar for damp masonry: impact on laboratory evaluation. J Cult Herit. 2019;37:82-93. https://doi. org/10.1016/j.culher.2018.11.011.

64. Wiggins D. Traditional lime mortars and masonry preservation. J Build Limes Forum. 2017;24:28-37.

65. Orr SA, Young M, Fusade L, Stelfox D, Viles HA, Leslie A, et al. Moisture monitoring of stone masonry: a comparison of microwave and radar on a granite wall and a sandstone tower. Prep.

66. Stefanidou M. The role of compaction in the quality of repair. In: International RILEM workshop on repair mortars for historic masonry. Delft; 2005. p. 339-44.

\section{Publisher's Note}

Springer Nature remains neutral with regard to jurisdictional claims in published maps and institutional affiliations. 